\title{
Non-Viral in Vitro Gene Delivery: It is Now Time to Set the Bar!
}

\author{
Nina Bono ${ }^{1,+}$ (i) , Federica Ponti ${ }^{1,2,+}$, Diego Mantovani $^{2}$ and Gabriele Candiani $1, *$ (i) \\ 1 GenT Lab, Department of Chemistry, Materials and Chemical Engineering “G. Natta”, Politecnico di Milano, \\ 20131 Milan, Italy; nina.bono@polimi.it (N.B.); federica.ponti@polimi.it (F.P.) \\ 2 Laboratory for Biomaterials and Bioengineering, Canada Research Chair I in Biomaterials and \\ Bioengineering for the Innovation in Surgery, Department of Min-Met-Materials Engineering \& Research \\ Center of CHU de Quebec, Division of Regenerative Medicine, Laval University, Quebec City, QC G1V 0A6, \\ Canada; diego.mantovani@gmn.ulaval.ca \\ * Correspondence: gabriele.candiani@polimi.it; Tel.: +39-02-2399-3181 \\ $\dagger$ These authors equally contributed to this work.
}

Received: 3 February 2020; Accepted: 19 February 2020; Published: 21 February 2020

check for updates

\begin{abstract}
Transfection by means of non-viral gene delivery vectors is the cornerstone of modern gene delivery. Despite the resources poured into the development of ever more effective transfectants, improvement is still slow and limited. Of note, the performance of any gene delivery vector in vitro is strictly dependent on several experimental conditions specific to each laboratory. The lack of standard tests has thus largely contributed to the flood of inconsistent data underpinning the reproducibility crisis. A way researchers seek to address this issue is by gauging the effectiveness of newly synthesized gene delivery vectors with respect to benchmarks of seemingly well-known behavior. However, the performance of such reference molecules is also affected by the testing conditions. This survey points to non-standardized transfection settings and limited information on variables deemed relevant in this context as the major cause of such misalignments. This review provides a catalog of conditions optimized for the gold standard and internal reference, $25 \mathrm{kDa}$ polyethyleneimine, that can be profitably replicated across studies for the sake of comparison. Overall, we wish to pave the way for the implementation of standardized protocols in order to make the evaluation of the effectiveness of transfectants as unbiased as possible.
\end{abstract}

Keywords: non-viral gene delivery; cationic polymers; PEI; polyplexes; in vitro transfection; physico-chemical characterization; variability; reproducibility; standardization

\section{Introduction}

The delivery of nucleic acids (NAs) to mammalian cells (a process named transfection) has emerged as a new breakthrough in molecular medicine for the treatment at a genetic level of several diseases, including inherited disorders, some types of cancer, and certain viral infections [1-4], and in fundamental research and bionanotechnology for the investigation of basic cellular mechanisms or the production of specific proteins [5-7].

As a rule of thumb, gene delivery involves the deliberate modulation of gene expression patterns through the delivery of exogenous genetic material, such as (i) chimeric circular plasmid DNAs (pDNAs), which are hybrid plasmids with an expression cassette containing a specific gene of interest (such as a reporter gene encoding for an easily traceable protein, e.g., luciferase or a fluorescent protein), (ii) messenger RNA (mRNA), (iii) short regulatory RNAs such as short-interfering RNAs, micro RNAs, and short hairpin RNAs (siRNA, miRNA, and shRNA, respectively), and (iv) antisense oligonucleotides (ASOs) [1,8] into the target site of action (Table 1). 
Table 1. The major types of NAs used in gene delivery applications and their specific features.

\begin{tabular}{cccc}
\hline Nucleic Acid & Description & Site of Action & Applications/Pathway \\
\hline $\begin{array}{c}\text { pDNAs (also called chimeras) } \\
{[1,9]}\end{array}$ & $\begin{array}{c}\text { large circular dsDNAs } \\
(<10 \mathrm{kbp})\end{array}$ & nucleus & $\begin{array}{c}\text { nuclear localization followed by } \\
\text { transgene expression under } \\
\text { specific promoters to induce } \\
\text { protein expression }\end{array}$ \\
\hline mRNAs [1,9] & large ssRNAs $(<10 \mathrm{kbp})$ & cytosol & $\begin{array}{c}\text { positive regulation of protein } \\
\text { expression }\end{array}$ \\
\hline $\begin{array}{c}\text { short regulatory RNAs } \\
(\text { siRNAs/miRNAs/shRNA }[1,9]\end{array}$ & $\begin{array}{c}\text { short regulatory RNA } \\
(15-30 \mathrm{nt})\end{array}$ & cytosol & $\begin{array}{c}\text { RNA interference mechanisms to } \\
\text { shorten mRNA half-life and } \\
\text { downregulate translation }\end{array}$ \\
\hline ASOs [10] & $\begin{array}{c}\text { short DNA, RNA or } \\
\text { analogs }(15-30 \mathrm{nt})\end{array}$ & $\begin{array}{c}\text { cytosol and } \\
\text { nucleus }\end{array}$ & $\begin{array}{c}\text { RNA alteration to reduce, restore, } \\
\text { or modify protein expression }\end{array}$ \\
\hline
\end{tabular}

dsDNA = double stranded DNA; bp = base pair; ssRNA = single stranded RNA; $n t=$ nucleotide.

Although the delivery of naked NAs is considered the safest way to transfect cells, such a process is unfortunately ineffective. As a matter of fact, NAs cannot freely cross the cytoplasmic membrane because of the electrostatic repulsions occurring at physiological $\mathrm{pH}$ between the anionic NAs and the negatively charged plasma membrane. Yet, NAs suffer from limited extracellular stability. In fact, the genetic material is very prone to degradation by extracellular nucleases present in bodily fluids (in vivo) and in general extracellular milieu (in vivo and in vitro).

In order to address these issues, in the last decades, great efforts have been devoted to devising suitable approaches and tools to improve the delivery efficiency of NAs into target cells. Such strategies can be broadly classified into two main categories (Table 2), namely gene delivery methods and vectors [11,12].

Physical/mechanical methods, such as electroporation [13-15], sonoporation [16-18], magnetofection [19,20], optoporation [21,22], gene gun [23], and microinjection [24-26], attempt to force naked NAs into the cytosol or nucleus to achieve successful transfection $[27,28]$. Although conceptually simple yet powerful means for transfecting cells, such methods are however expensive and somehow inconvenient for most gene delivery applications [29]. In this survey, we deliberately avoid dealing with physical methods-mediated gene delivery.

The other popular way to deliver NAs into mammalian cells relies on the use of gene delivery carriers, also known as systems or vectors, which can be further categorized into viral and non-viral ones. An ideal gene delivery vector should be effective, specific, and safe [30-33].

As viruses are highly evolved biological systems that effectively gain access to host cells by nature, engineered viral vectors, that is, viruses in which the therapeutic gene cassette is in place of part of the viral genome, are so far the most widely used vehicles in gene therapy [34-37]. Despite these unique strengths, they are still plagued by inherent issues such as the limited size of NAs that can be packed and delivered, random recombination (i.e., oncogenic potential), cytotoxicity, and immunogenicity $[38,39]$. These concerns, together with the high costs related to large-scale production and quality control, have steered research towards non-viral carriers $[40,41]$. 
Table 2. Overview of the different transfection technologies for gene delivery applications.

\begin{tabular}{|c|c|c|c|c|}
\hline & Strategy & Description & Pros & Cons \\
\hline \multirow{6}{*}{$\begin{array}{c}\text { Physical/ } \\
\text { mechanical } \\
\text { methods } \\
{[27,29,42]}\end{array}$} & electroporation & $\begin{array}{l}\text { application of an electric field by voltage pulses } \\
\text { to induce transient cell membrane poration }\end{array}$ & $\begin{array}{l}\text { high efficiency; low costs; high reproducibility; } \\
\text { ability to transfer large size DNA }\end{array}$ & $\begin{array}{l}\text { tissue/cell damage; invasiveness; some } \\
\text { DNA instability }\end{array}$ \\
\hline & sonoporation & $\begin{array}{l}\text { use of highly-focused ultrasounds to trigger } \\
\text { transient cell membrane poration }\end{array}$ & $\begin{array}{c}\text { non-invasiveness; possibility to be used in } \\
\text { combination with microbubbles/non-viral } \\
\text { vectors }\end{array}$ & $\begin{array}{l}\text { low efficiency; low reproducibility; } \\
\text { tissue/cell damage }\end{array}$ \\
\hline & optoporation & $\begin{array}{l}\text { use of short ultra-focused laser pulses to induce } \\
\text { transient cell membrane poration }\end{array}$ & high efficiency; high spatial precision & $\begin{array}{l}\text { tissue/cell damage; low irradiation area; } \\
\text { poor penetration of the laser pulses }\end{array}$ \\
\hline & magnetofection & $\begin{array}{l}\text { application of a magnetic field to ease the } \\
\text { transfer of NAs-coated paramagnetic particles } \\
\text { into cells }\end{array}$ & $\begin{array}{l}\text { high efficiency; non-invasiveness; possibility to } \\
\text { be used in combination with non-viral vectors }\end{array}$ & $\begin{array}{l}\text { poor efficiency with naked DNA; possible } \\
\text { agglomeration of magnetic particles }\end{array}$ \\
\hline & microinjection & $\begin{array}{l}\text { direct injection of NAs into single cells by means } \\
\text { of a needle }\end{array}$ & $\begin{array}{l}\text { high efficiency; simplicity; reproducibility; low } \\
\text { cytotoxicity; ability to transfer large size DNA }\end{array}$ & $\begin{array}{l}\text { time consuming; inability to transfect } \\
\text { large number of cells }\end{array}$ \\
\hline & gene gun & $\begin{array}{l}\text { propulsion of NAs-coated particles towards the } \\
\text { target site }\end{array}$ & high efficiency; safety & $\begin{array}{l}\text { tissue/cell damage; poor penetration of } \\
\text { particles }\end{array}$ \\
\hline \multirow{5}{*}{$\begin{array}{l}\text { Viral vectors } \\
{[2,39,43,44]}\end{array}$} & adenoviruses (AdVs) & $\begin{array}{l}\text { non-enveloped dsDNA-virus able to carry } \leq 8 \\
\text { kbp DNA }\end{array}$ & efficient in a broad range of host cells & $\begin{array}{l}\text { high immunogenicity; transient } \\
\text { expression }\end{array}$ \\
\hline & $\begin{array}{l}\text { adeno-associated } \\
\text { viruses (AAVs) }\end{array}$ & $\begin{array}{l}\text { non-enveloped recombinant ssDNA-virus with } \\
\text { a small carrying capacity ( } \leq 4 \mathrm{kbp})\end{array}$ & $\begin{array}{l}\text { efficient in a broad range of host cells; } \\
\text { non-inflammatory/pathogenic }\end{array}$ & small carrying capacity \\
\hline & retroviruses & $\begin{array}{c}\text { enveloped ssRNA-carrying virus with } \leq 8 \mathrm{kbp} \\
\text { RNA capacity }\end{array}$ & long-term expression & $\begin{array}{c}\text { limited tropism to dividing cells; random } \\
\text { integration }\end{array}$ \\
\hline & lentiviruses & $\begin{array}{c}\text { enveloped ssRNA-carrying virus with } \leq 8 \mathrm{kbp} \\
\text { RNA capacity }\end{array}$ & $\begin{array}{l}\text { efficient in a broad range of host cells; long-term } \\
\text { expression }\end{array}$ & potential oncogenic responses \\
\hline & $\begin{array}{l}\text { herpes simplex viruses } \\
\text { (HSV)-1 }\end{array}$ & $\begin{array}{l}\text { enveloped dsDNA-virus with }>30 \text { kbp carrying } \\
\text { capacity }\end{array}$ & $\begin{array}{l}\text { large packing capacity; efficient in a broad range } \\
\text { of host cells }\end{array}$ & $\begin{array}{l}\text { potential inflammatory responses; } \\
\text { transient expression }\end{array}$ \\
\hline \multirow{3}{*}{$\begin{array}{l}\text { Non-viral } \\
\text { vectors } \\
{[11,45-48]}\end{array}$} & $\begin{array}{c}\text { inorganic } \\
\text { nanoparticles }\end{array}$ & $\begin{array}{c}\text { metal-based nanoparticles of different size and } \\
\text { shapes }\end{array}$ & possibility of functionalization; low cytotoxicity & instability; toxicity \\
\hline & cation lipids & $\begin{array}{l}\text { lipids able to self-assemble with NAs to give } \\
\text { lipoplexes }\end{array}$ & tunable features; safety; low cytotoxicity & low transfection efficiency \\
\hline & cationic polymers & $\begin{array}{l}\text { polymers able to self-assemble with NAs to give } \\
\text { polyplexes }\end{array}$ & $\begin{array}{l}\text { tunable features; possibility of functionalization; } \\
\text { mild cytotoxicity; stability in protein-rich media; } \\
\text { low cytotoxicity }\end{array}$ & low transfection efficiency \\
\hline
\end{tabular}


Since the inception of inorganic matter for plasmid delivery in the 1970s [49], the last decades have thus witnessed a surge of interest in non-viral systems [1,50-52]. Because they are relatively safe, display easily tunable physico-chemical properties, can be produced in large quantities with high reproducibility and affordable costs, and show unlimited ferrying capacity [53-55], non-viral vectors are nowadays at the forefront of gene delivery [1]. The two major approaches to non-viral gene delivery involve the combination of NAs with transfection molecules, that is, cationic lipids (CLs; e.g., DOTAP, DOTMA) [56-61] in different forms, and cationic polymers (CPs; e.g., poly-L-lysines, polyethyleneimines (PEIs), poly(amidoamine)s, chitosans) [62-67]. The beauty of this approach lies in its simplicity, yet in its effectiveness. Indeed, such positively charged (poly)electrolytes self-assemble with the anionic NAs to give rise to particle-like complexes (lipoplexes and polyplexes when complexation involves CLs and CPs, respectively), having sizes ranging from tens of $\mathrm{nm}$ to few $\mu \mathrm{m}$, which are able to sneak through the cell membrane and allow NAs internalization into cells [12].

With the use of contemporary tools and techniques, it has become possible to somehow tune the performance of non-viral vectors for gene delivery [68]. Nevertheless, despite a large variety of reagents that has been developed worldwide with some success (for comprehensive reviews, refer to $[11,69-71])$, the design of more and more effective gene delivery vectors is still painfully slow. Whatever the strategy used, success largely depends first on gathering reliable data from the literature. As for other biomedical subjects [72-76], lab-to-lab variability in routine transfection protocols in vitro (as depicted in Figure 1), that is, the lack of standard test procedures, has largely contributed to the huge number of inconsistent findings underpinning the reproducibility crisis. Indeed, scientists are flooded with data that are hard to digest, compare, and integrate into a clear view of how to design a transfectant with superior behavior.

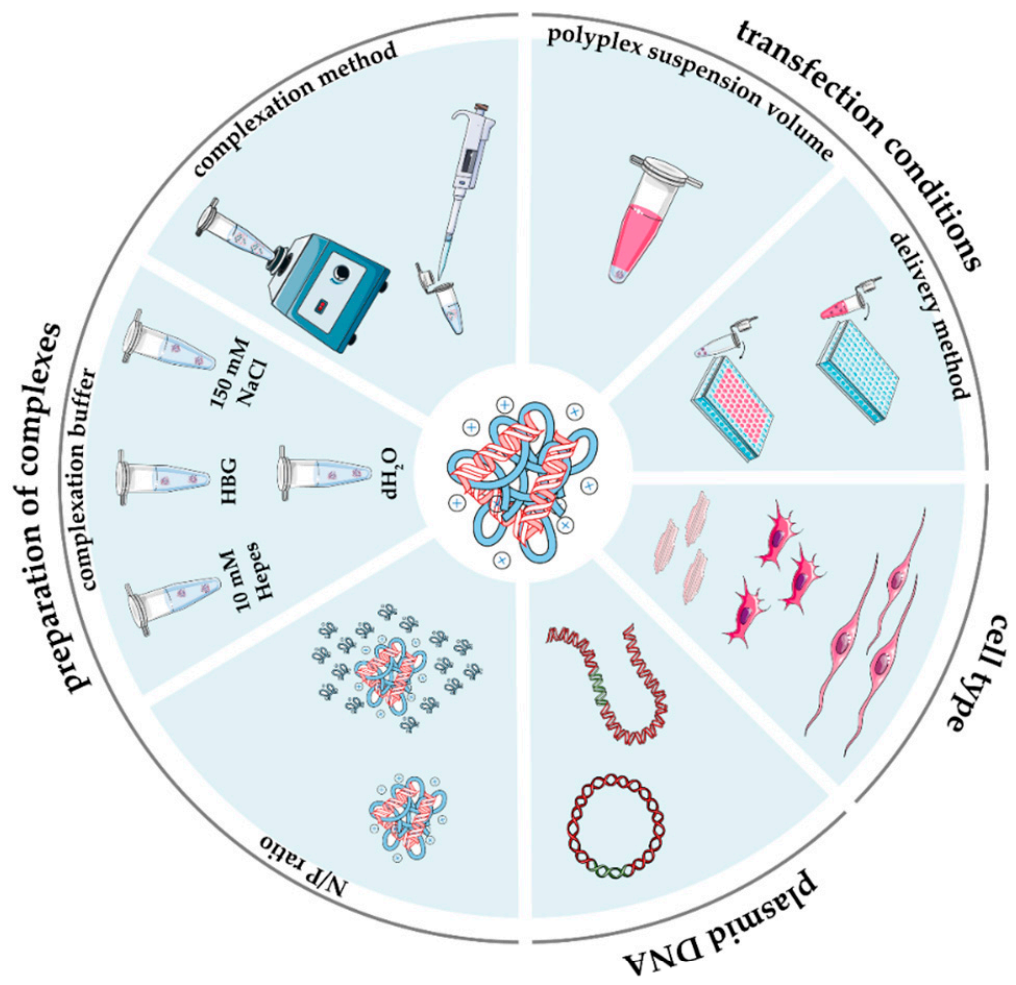

Figure 1. Main experimental parameters influencing the in vitro performance of gene delivery vectors.

Herein, we seek to highlight the issues involved and suggest ways in which this process can be expedited and improved. A key question is how robust the approaches are to screening and implementing new gene delivery vectors, and what measures could be taken into account to shorten the long and protracted development of new transfectants. This review seeks to provide the readers with a 
precise and clear catalog of issues that, to different extents, may affect the effectiveness of non-viral gene delivery vectors. A thorough survey of literature data and some genuine findings disclosed herein, taking as an example the complexes prepared using model molecules polyethyleneimine (PEI) and pDNA (for the exhaustive description of the experimental setups, please refer to the supplementary materials), aim to fill the multiple gaps in bibliographic information and shed light on the profound impact of common experimental parameters—too often neglected—on the in vitro transfection behavior of gene delivery vehicles.

\section{Non-Viral Gene Delivery Using Plasmid DNA and Cationic Polymers}

\subsection{Plasmid DNA}

Whether considering the sole use of DNA, some variations in the transfection efficiency may rely on differences in the topology of the DNA being transferred. Previous studies from the Uludağ's group have shed light on the greater transgene expression given by circular pDNA as compared to its linearized counterpart [77]. Similar findings have been reported for CLs as well [78]. Yet, other DNA topologies (e.g., supercoiled, open-circular, and linear) have been found to affect the expression of the transferred NAs [79]. Of note, the supercoiled pDNA (sc-pDNA) is widely recognized as the least susceptible to intracellular degradation and, as such, it is considered the most physiologically active pDNA to be used to transfect mammalian cells [79]. The mechanism underlying the influence of the DNA topology on the ultimate transfection efficiency is, however, still unknown. Nevertheless, it was found that sc-pDNA displays a very tiny hydrodynamic size that, in turn, may be responsible for its great intracellular mobility through entangled and cross-linked composite networks of actin and microtubules [78-83].

Generally speaking, pDNAs used for in vitro transfection studies vary not only in the specific reporter gene sequence they were endowed with (e.g., firefly luciferase, green fluorescence protein (GFP)), but also in other basic elements. An illustrative example of this issue relies on multicistronic constructs (i.e., pDNAs that express multiple genes at once, leading to the production of two or more separate proteins from the same mRNA) [84]. Alongside this, a specific promoter must be carefully selected in order to drive the constitutive overexpression of the transgene(s) in the specific host. Commercially sourced promoters, namely, human cytomegalovirus (CMV), simian vacuolating virus 40 (SV40), and elongation factor (EF)-1 [85-87], have shown some cell type-dependent specificity. Instead, it was shown that the CMV promoter invariably induces the highest transgene expression in any of the cell lines tested [88], and in differentiated cells, but was unable to do so in pluripotent stem cells [89].

Altogether, these findings allow us to pinpoint the features of a given gene construct that may affect the transfection outcomes in vitro. In this context, the most effective pDNA to be used for gene delivery purposes is in the form of sc-pDNA, which is typically obtained through its resuspension in $0.1 \times$ TE buffer $(10 \mathrm{mM}$ Tris- $\mathrm{HCl}, \mathrm{pH} 8.0$, and $1 \mathrm{mM}$ disodium ethylenediaminetetraacetic acid (EDTA)) [90]. For a matter of consistency, reproducibility, and in order to ease the comparison of results, the exact name and/or code of the pDNA used for transfection have to be disclosed. As such, this implies that all the information about the size, promoter, and transgene expressed are to be made public. Furthermore and whenever possible, any noticeable information about pDNA (super)coiling, or at least information about the resuspension buffer used, must be very detailed.

\subsection{Cationic Polymers (CPs)}

In the last decades, huge efforts have been devoted to engineering and identifying the ideal vector able to overcome the major physiological bottlenecks of gene delivery, namely cellular internalization, endosomal escape, pDNA translocation from the cytosol to the nucleus, and NAs release [68]. CPs are amongst the most utilized non-viral vectors for gene transfer (for comprehensive reviews on polymeric carriers, see $[9,69,91,92])$, which consist of multiple, positively charged residues, such as 
primary, secondary, tertiary amines, as well as amidines, guanidino, and triazino groups, which act as DNA-binding moieties during polyplexes formation. Besides, they can display different chemistries and architectures [93]. CPs include commercially sourced materials (Figure 2), such as poly-L-lysines (PLLs) [94,95], poly(ethyleneimines) (PEIs) [96,97], poly(amidoamines) (PAMAMs) [64, 98-101], poly[2-(dimethyamino)ethyl methacrylates] (PDMAEMs) [102], and chitosans (CSs) [103-106], used as received or reacted and functionalized [63,107-110], and those purposely synthesized [111].

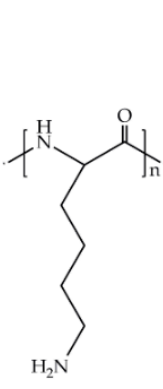

PLL<smiles>CCNCCNCCNCCNCCNCCN</smiles>

IPEI

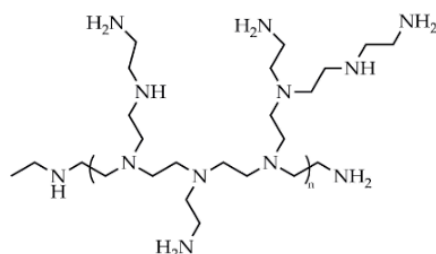

$b$ PEI

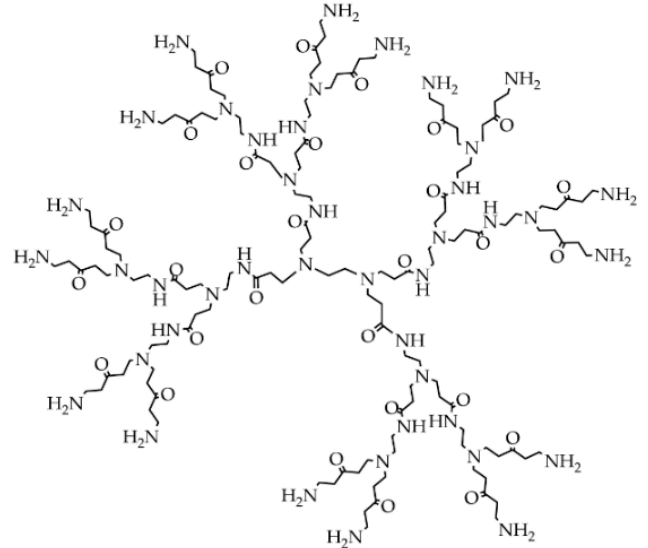

PAMAM

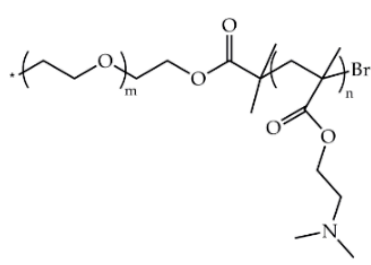

PDMAEM

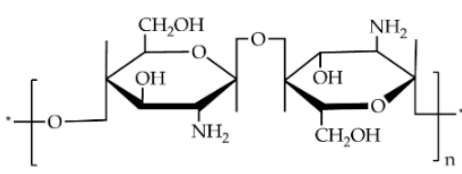

chitosan

Figure 2. Chemical structures of commonly used cationic polymers for gene delivery purposes.

Of note, the efficacy of a transfectant strongly depends on some chemical and geometrical features. PEI is one of the most utilized non-viral polymeric vectors for gene delivery applications $[69,112]$ due to its extremely high cation charge density. Depending on the way that the repeating ethylenimine units link together, that is, the way of polymerization, it occurs as linear (lPEI) or branched (bPEI) isomers (Figure 2) [111]. Other features, such as the degree of polymerization (molecular weight $\left(\mathrm{M}_{\mathrm{W}}\right)$, branching degree in the case of $b \mathrm{PEI}$ only, polydispersity) and the buffering capacity, which is strictly related to the cationic charge density, have an impact on the vector performances [112]. For instance, while $l \mathrm{PEI}$ and $b \mathrm{PEI}$ of equal $\mathrm{M}_{\mathrm{W}}$ show similar transfection efficiencies [113], there is no general consensus as to which is the most effective $\mathrm{M}_{\mathrm{W}}$ of PEI in transfection. Some authors have indeed reported that the transfection efficiency of $b \mathrm{PEI}$ in vitro increased with increasing the $\mathrm{M}_{\mathrm{W}}$ of the $\mathrm{CP}$ (in the range from $\approx 1.8$ to $\approx 70 \mathrm{kDa}$ ) [62,114], while others have highlighted that the lower the $\mathrm{M}_{\mathrm{W}}$ of the branched polymer $(\approx 12 \mathrm{kDa})$, the greater the effectiveness [115]. Further, we and some others have pointed out the different pDNA complexation ability of $l$ PEI and $b$ PEI and have found that, irrespective of the $\mathrm{M}_{\mathrm{W}}$ of the $\mathrm{CP}$ taken into account, 1 PEIs complex best at $\mathrm{N} / \mathrm{P} 5$, while bPEIs at N/P $3[57,62,64,116,117]$. This different behavior may be ascribed to the different structures of the PEI isomers: of note, $l$ PEI possesses only secondary amines, while bPEI has primary, secondary, and tertiary amines depending on the polymerization degree [118]. These account for the buffering capacity of the $b$ PEI over a wide range of $\mathrm{pH}$ and, in turn, for the "proton-sponge effect" underpinning the escape of polyplexes from the endo/lysosomes.

Overall, the good gene delivery performances of PEIs, together with moderate cytotoxicity they exert, disclose this class of CPs as gold standard transfectants. As such, they have been largely used 
as benchmark transfectants in most of the in vitro studies [57,112]. As a rule of thumb, according to ISO norms, reference materials are those whose properties are sufficiently homogeneous and well established to be used for assigning values to other materials $[119,120]$, which in practice means to other transfectants being developed. This notion implies that a reference material has to be used under very defined and controlled conditions so that its activity is kept as constant as possible. In reality, there remain substantial inter-laboratory variability issues related to the effectiveness of PEI-based transfections that may depend on the gene delivery protocols adopted, the use of different raw materials (e.g., the type and dose of pDNA used, specific transfectant features), various pDNA/transfectant complexation conditions (e.g., N/P; complexation buffer; complexation temperature and time), specific complex doses administered to cells and cell culture conditions, different read-out systems, among others (Figure 1). All of this makes it dramatically difficult to fairly compare results between laboratories.

\subsection{Preparation of Complexes}

Despite the increasingly sophisticated analytical techniques available to evaluate the physico-chemical properties and biological behavior of gene delivery assemblies, real progress in the field of non-viral gene delivery is rather limited. However, this issue is symptomatic of far broader challenges in biomedical research that cannot be addressed by simply identifying suitable methods or techniques to carry out a given analysis [121]. Rather, we have brought some features into prominence, i.e., the DNA complexation ability of a $\mathrm{CP}$, the size and surface charge of complexes, the milieu in which complexation occurs, that play a causative role in the transfection effectiveness of the resulting complexes. These will, therefore, be dealt with separately herein below.

\subsubsection{Cationic Polymer-to-Plasmid DNA Ratio}

It is a matter of fact that the performances of polyplexes are largely dependent on the (mole or mass) ratio between the transfectant used for complexation and the NAs to be packed and delivered. Complexes are prepared by mixing a $\mathrm{CP}$ with pDNA while taking into account that the cationizing groups (typically amines) of the transfectant are the only moieties able to bind electrostatically to the anionic phosphates of the NA. In the most common and simplest case, such charge ratio is basically the ratio between the basic nitrogen $(\mathrm{N})$ moles of the transfectant and the phosphate $(\mathrm{P})$ moles borne by a given pDNA quantity and is referred to as the N/P ratio [122]. To put this definition into practice, we take for example the PEI molecule. Every basic amino group of the $\mathrm{CP}$ has to be regarded as potentially responsible for DNA binding, that is, one $\mathrm{N}$ per repeat unit of $\mathrm{PEI}\left(-\mathrm{NHCH}_{2} \mathrm{CH}_{2}-\mathrm{M}_{\mathrm{W}}\right.$ $=43 \mathrm{Da}$ ) $[62,123]$. For a pDNA (i.e., a dsDNA), instead, one can calculate the phosphate (P) moles according to the Equations (1) and (2):

$$
P \text { moles }=d s D N A \text { moles } \times d s D N A \text { length }(b p) \times 2
$$

where

$$
d s D N A \text { moles }=\frac{d s D N A \text { mass }(g)}{d s D N A \text { length }(b p) \times M W_{b p}}
$$

As a general rule, there are $\approx 3 \mathrm{nmol}$ of $\mathrm{P}$ every $\mu \mathrm{g}$ of pDNA.

When dealing with the in vitro screening of transfection agents, the minimum ratio at which the pDNA is fully complexed into particles must be pinpointed, so that no naked and ineffective NA is delivered to cells. It is worth noting that this conditio seldom gives rise to the most effective particles in transfection experiments. For instance, if considering the model $l \mathrm{PEI}$, the transfection efficiency of polyplexes increases along with the N/P (Figure 3a). We can speculate that the presence of single free PEI molecules in solution (at N/P 10, $\approx 50 \%$ of PEI is in the form of free CPs) contributes to the stability of the particles, in terms of ultimate size (usually expressed as hydrodynamic diameter, $\mathrm{D}_{\mathrm{H}}$ ) and surface charge (usually expressed as zeta potential, $\zeta_{\mathrm{P}}$ ) (Figure $3 \mathrm{~b}$ ), and destabilizes the cellular membrane, promoting the internalization of polyplexes and improving the transfection efficiency [117]. 

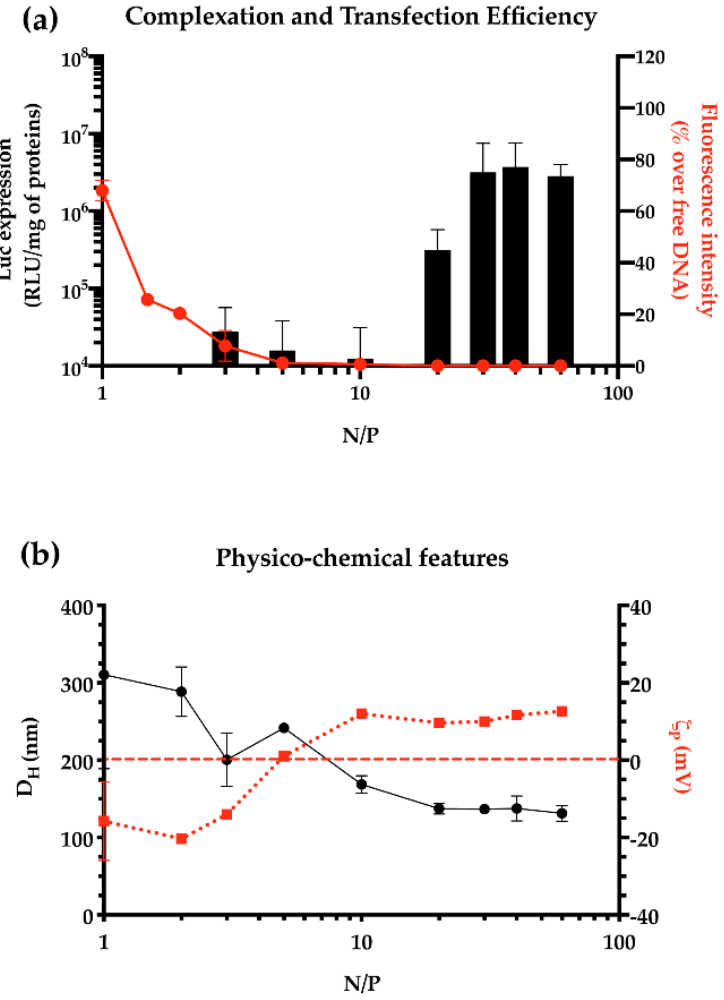

Figure 3. DNA complexation ability, transfection efficiency, and physico-chemical characteristics of pDNA/lPEI complexes prepared in $10 \mathrm{mM}$ Hepes at different N/Ps. (a) Transfection efficiency (black bars) in L929 cells of pDNA/lPEI complexes prepared at different N/Ps. Results are expressed as luminescence signal (RLU) normalized to the total protein content in each cell lysate, and the DNA complexation ability of $l$ PEI (red dots, solid line), evaluated by monitoring the fluorochrome exclusion from complexes as a function of the N/P. (b) Mean hydrodynamic diameter $\left(\mathrm{D}_{\mathrm{H}}\right.$, black dots solid line) and overall surface charge $\left(\zeta_{\mathrm{P}}\right.$, red squares and dotted line) of pDNA/lPEI complexes at different N/Ps, as measured by dynamic light scattering (DLS) and electrophoretic light scattering (ELS), respectively. Results are expressed as mean $\pm \operatorname{SD}(n \geq 3)$.

Thus, when evaluating the performance of a gene delivery vector, one should first find out the minimum N/P for effective complexation of a given amount of DNA, and next, the optimal N/P that allows for the greatest transfection and the lowest cytotoxicity in vitro.

\subsubsection{Polymer Solubilization and Complexation Buffer}

Because non-viral gene delivery particles are formed by electrostatic interactions [111,124], they are sensitive to the composition of the medium (i.e., the saline composition, the ionic strength, and the $\mathrm{pH}$ ) in which the complexation occurs. The most widely used buffers for complexation are 10 mM Hepes [62,96], whether supplemented or not with $5 \%(w / v)$ glucose (hereafter referred to as HBG buffer) [125], $150 \mathrm{mM} \mathrm{NaCl}[126,127]$, and deionized water $\left(\mathrm{dH}_{2} \mathrm{O}\right.$ or MilliQ) [128].

The transfection efficiency profiles (Figure $4 a$ ) observed in vitro when using pDNA/lPEI complexes prepared in different buffers reflect their different physico-chemical features in a size- and surface charge-dependent manner (Figure $4 b, c$, respectively). Literature data and our own findings agree that, in the presence of physiological salt concentrations (e.g., $150 \mathrm{mM} \mathrm{NaCl}$ ), $25 \mathrm{kDa} l \mathrm{PEI}$ forms large polyplexes of $\approx 1 \mu \mathrm{m}$ in size. Instead, rather smaller complexes of $\approx 200 \mathrm{~nm}$ are obtained in $\mathrm{dH}_{2} \mathrm{O}$ and a low-salt buffer (10 mM Hepes). On the other hand, the addition of glucose to the latter (i.e., HBG) allows us to obtain smaller pDNA/lPEI assemblies with a $\mathrm{D}_{\mathrm{H}}$ of $\approx 100 \mathrm{~nm}$ (Figure 4 and Table S1). It is worth noting that the greater the particles, the faster their settling and the higher the transfection efficiency in adherent cells. Hence, lPEI-based complexes prepared in $150 \mathrm{mM} \mathrm{NaCl}$ (i.e., those with the 
greatest hydrodynamic size (Figure $4 b$ )) settle onto cell monolayers in a similar way that the calcium phosphate-mediated transfection does [129], resulting in an ultimate transfection efficiency $\approx 10$-fold higher than the other conditions (Figure $4 \mathrm{a}$ ). Likewise, polyplexes with higher surface charge (i.e., $\left.\zeta_{\mathrm{P}}\right)$ are much more effective in transfecting adherent cells in vitro (see Figure 4a,c, and [130]) due to their favorable binding with the cell membrane.
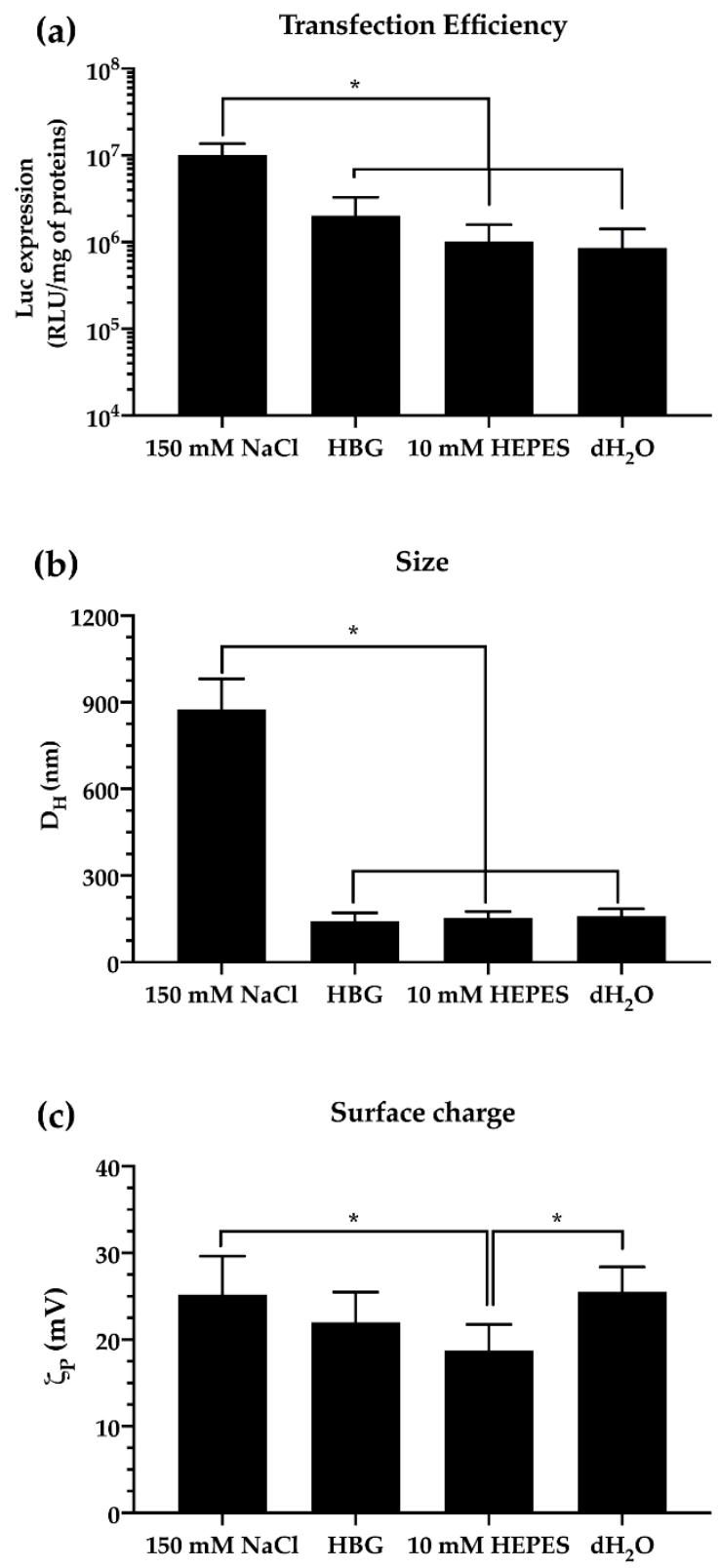

Figure 4. Effect of complexation buffer on the transfection efficiency and physico-chemical features of pDNA/lPEI polyplexes prepared at N/P 30 in L929 cells. (a) Transfection efficiency of pDNA/lPEI complexes prepared in different buffers. Complexes were prepared by adding $160 \mathrm{ng} / \mathrm{cm}^{2}$ of pGL3 to the $l$ PEI solution. $(\mathbf{b})$ Hydrodynamic diameter $\left(\mathrm{D}_{\mathrm{H}}\right)$ and $(\mathbf{c})$ overall surface charge $\left(\zeta_{\mathrm{P}}\right)$ of pDNA/lPEI complexes prepared by adding $1 \mu \mathrm{g}$ of pDNA to the $l \mathrm{PEI}$ solution, then complexes were diluted in different buffers. Measurements were carried out by means of a dynamic light scattering (DLS; for $\mathrm{D}_{\mathrm{H}}$ measurements) and electrophoretic light scarring (ELS; for $\zeta_{\mathrm{P}}$ measurements) apparatus. Results are expressed as mean $\pm \mathrm{SD}(\mathrm{n} \geq 3)(* p<0.05)$. 
Given the above, it is apparent how the physico-chemical features and the actual biological effectiveness of non-viral gene delivery assemblies in vitro can be fine-tuned as a function of the ionic strength and the overall salinity of the dispersing medium. Besides, as the ionic strength dramatically affects the amine protonation, which impacts the interactions between PEI molecules and NAs or cell membranes [131], the way PEIs are solubilized in aqueous solutions and buffered at physiological $\mathrm{pH}$ are very fundamental facets that deserve some attention. Such cues should all be given due consideration when preparing PEI-based complexes and should be explicitly stated in the manuscript. In addition, the physico-chemical features of complexes should also be systematically evaluated in the context of their use, such as in the biological medium where transfection assays will be carried, and the type of cells used (anchorage-dependent, adherent vs. suspension culture). Yet, the temporal evolution of the $\mathrm{D}_{\mathrm{H}}$ when the polyplexes are diluted in the culture medium should also be taken into account. Indeed, because culture media are rich in serum proteins that adsorb onto the polyplex surface to give the so-called protein corona $[96,122,132]$, the $\mathrm{D}_{\mathrm{H}}$ of polyplexes evolves over time in such dispersants [133].

Different analytical technologies, each one with specific pros and cons [134], are currently used for the evaluation of the physico-chemical characteristics of gene delivery complexes, such as atomic force microscopy (AFM), scanning electron microscopy (SEM), transmission electron microscopy (TEM), microfluidic resistive pulse sensing (MRPS), and the most widely used dynamic light scattering (DLS) [135]. In order to make the characterization as thorough and comprehensive as possible, at least a couple of the above should be used.

\subsubsection{Complexation Method}

One of the most underappreciated, if not neglected, issues is the dramatic effect that some minor changes in the way of blending the single components (i.e., the pDNA and the CP solutions) may have on the ultimate polyplex behavior in vitro. Indeed, sharply different complexes are generated by adding the pDNA solution to a large excess of transfectant solution (for instance at a ratio of $\approx 1: 10$ $(v / v))$ or vice versa, or when DNA solution is added to the PEI equivolume $(v / v)$ (Figure $5 a)$. Moreover, being the complexation an entropy-driven process [136], the way the pDNA is added to and mixed with the PEI solution, that is, (i) the addition of one solution to the other one and the stirring of the resulting mixture by means of repeated and rigorous pipetting, (ii) the single dripping of one solution into another and subsequent rest, and (iii) the vigorous vortex and stirring of the two solutions once blended together, does affect the transfection outcomes (Figure $5 b$ ).

Even though the reasons underpinning these disparate behaviors are still somewhat unclear, the dripping of the pDNA solution into the $\mathrm{CP}$ solution is the most straightforward way to produce very effective polyplexes.

Together, these findings entail that each and every material (i.e., the pDNA, the $\mathrm{CP}$, and the compexation buffer) and the procedure used to prepare the transfection assemblies (i.e., the addition/mixing method) have an impact on their physico-chemical features and this, in turn, affects their transfection effectiveness in vitro. Accordingly, any time a benchmark transfectant is used to gauge the effectiveness of another gene delivery vector, the materials used and the procedures followed should be disclosed with a suitable level of detail. 

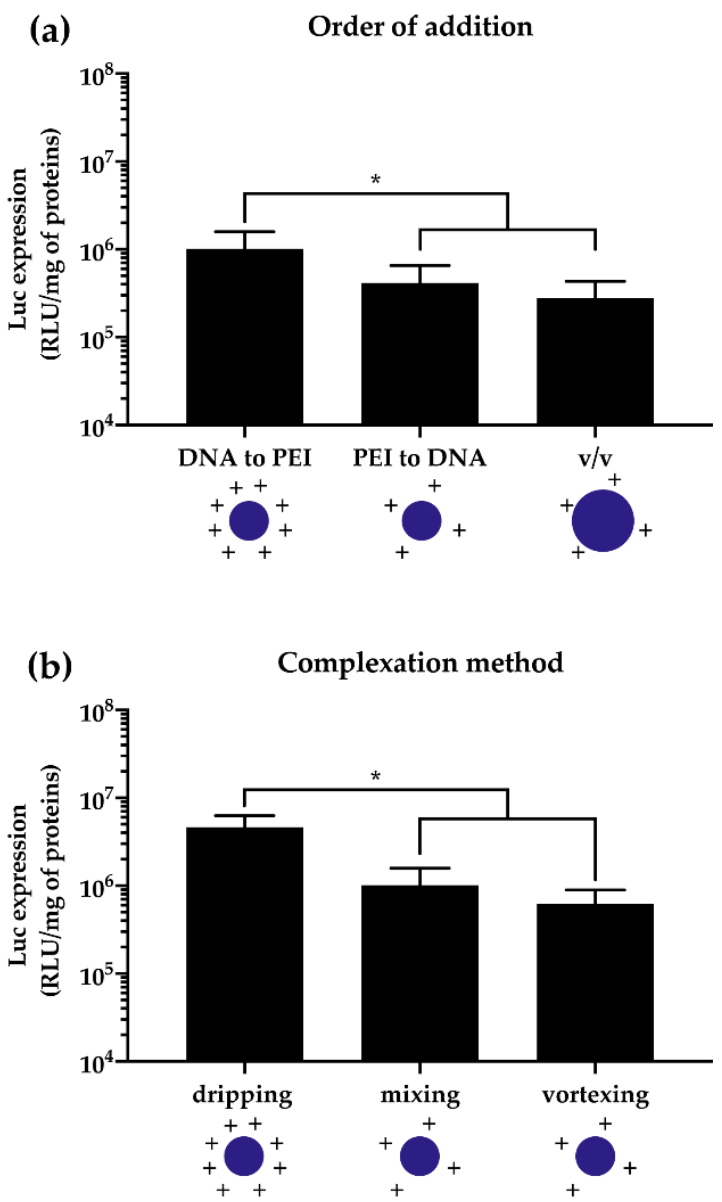

Figure 5. Effect of the complexation method on the transfection efficiency of pDNA/lPEI complexes at N/P 30 in L929 cells. (a) Transfection efficiency of pDNA/lPEI complexes as a function of the order of mixing and volumes of $l \mathrm{PEI}$ and pDNA solutions. Complexes were prepared by adding $160 \mathrm{ng} / \mathrm{cm}^{2}$ of pGL3 with the $l$ PEI solution in $10 \mathrm{mM}$ Hepes (DNA to PEI), or vice versa (PEI to DNA), then mixing the two solutions by rigorous pipetting, or by mixing equivolumes of DNA and PEI solutions ( $v / v)$. (b) Transfection efficiency of pDNA/lPEI complexes as a function of the complexation method. Complexes were prepared by adding $160 \mathrm{ng} / \mathrm{cm}^{2}$ of pGL3 to $l \mathrm{PEI}$ in $10 \mathrm{mM}$ Hepes by single dripping, mixing (i.e., repeated and rigorous pipetting), and vortexing. Results are expressed as mean $\pm \operatorname{SD}(n \geq 3)\left({ }^{*} p<0.05\right)$.

\section{Experimental Strategies and In Vitro Transfection Assays}

\subsection{Cell Type and Culture Conditions}

The vast majority of the transfection studies in vitro have been performed on adherent cell monolayers in multiwell culture plates. A large array of different replicating cells (i.e., immortalized cell lines, primary cells, and cancer cells), from different donor species (e.g., human, murine, monkey), and from diverse tissue types (e.g., endothelium, kidney, muscle) have been used for this purpose [68,137]. Because immortalized cell lines display high(er) proliferative rates, that is, short(er) doubling time, they are the first-choice option to check for the effectiveness of gene delivery systems. This is because the nuclear membrane temporarily disappears during each mitotic event in such a way that the pDNA becomes inherently accessible to the transcription machinery $[78,138,139]$. In this light, cell lines are easy-to-transfect cells because they multiply fast. Conversely, primary cells progressively take longer and longer to duplicate because they undergo senescence, and therefore are harder to transfect and require greater pDNA doses to reach even lower transfection efficiencies than cell lines [96]. Of note, pDNA-transfected cells transiently express the foreign gene; that is, it does not get integrated into the genome. As a result, no pDNA replication takes place over time. Consequently, the transgene is 
expressed only for a certain finite period of time and then is lost through cell division. Thus, on a per-cell basis, the shorter the doubling time, the greater the transfection efficiency and the less lasting the transgene expression.

Furthermore, cells require a certain confluence level to behave at best. Indeed, cell-to-cell interactions, in other words, direct cell-to-cell contact and communication, and secretion of diffusible factors between physically separated cells are a basic need for cell growth and division [140,141]. That is why the optimal cell density has to be properly selected to carry out transfection experiments, as pointed out in a recent paper [62].

Mycoplasma contamination is one of the major concerns that laboratories and commercial facilities employing cell lines have to face [142-144]. Indeed, mycoplasma are a common cause of cell contamination affecting about every fourth cell culture and endangering almost all aspects of cell physiology. Possible effects include the induction of chromosomal abnormalities, the disruption of DNA and RNA synthesis, changes in membrane antigenicity, the inhibition of cell proliferation and metabolism due to nutrient withdrawal, changes in gene expression profiles, and cell death, which result in decreased transfection rates $[145,146]$. These extensive effects of mycoplasma contamination on cultured cells make it clear that any data derived from mycoplasma-contaminated cell cultures, or any time cells are not verified mycoplasma-negative, are of questionable accuracy and should be treated with caution and suspicion. There are no tricks to avoiding mycoplasma contamination and other serious cell culture concerns. As cell culture techniques and applications become more complex, one must be aware of the impact of poorly controlled or suboptimal cell culture procedures. In this light, the doubling time, the passage number, and the cell confluence level are reliable indexes of how cells behave [147] and conceivably respond to transfection and, as such, they should be made explicit in the paper. Besides, in order to mitigate the risk of mycoplasma contamination, microbiological monitoring (e.g., through polymerase chain reaction (PCR)-based testing, [148-150]) is routinely required throughout cell culture and transfection. In this regard, the entire scientific community is rethinking mycoplasma contaminations, and high-impact factor journals either strongly recommend or even require regular cell testing. Obtaining and using low-passage cell lines from one of the world's leading repositories is a sure way to work and publish with confidence.

\subsection{Transfection Conditions}

In vitro transfection experiments aim to assess the overall performance of non-viral gene delivery vectors. Transfection assays have evolved through the past decades and are nowadays performed following in-home protocols and rely on different read-out systems. All this makes it difficult to directly compare the results of one researcher with those of another.

The amount of DNA, and consequently of complexes, to be delivered to cells is a key experimental factor to be taken into account when looking for the best possible transfection outcomes. Although gene delivery experiments are usually carried out over a very narrow range of pDNA doses, the literature agrees on the existence of a causal relationship between the transfection efficiency and the dose of NAs utilized in transfection [137]. Recently, we and others have pinpointed the pDNA dose of $160-320 \mathrm{ng} / \mathrm{cm}^{2}$ as the most effective in different cell lines (HeLa, COS-7, and HepG2 cells) transfected with both PEI isomers [62,137].

Furthermore, other parameters herein disclosed, such as the volume ratio between the polyplex suspension and the culture medium used during transfection of adherent cells (hereinafter referred to as the polyplex volume:medium volume ratio), and the way complexes are dispensed to cells in culture (Figure 6) have a striking effect on the transfection behavior of gene delivery vectors [62,63, $108,113,125,128,151-154]$. Specifically, the lower the transfectant volume:medium volume ratio (e.g., $\leq 1: 40$, which corresponds to deliver $\leq 2.5 \mu \mathrm{L}$ of complexes to cells cultured in a 96-multiwell plate format with $100 \mu \mathrm{L} /$ well of medium), the greater the transfection efficiency of polyplexes (Figure 6a). This is probably because cells are at their best, and thus are most permissive to transfection, when the concentration of the culture medium constituents is as close as possible to the standard culture 
conditions [137]. Besides, due to the presence of salts (i.e., ions) and proteins (i.e., polyions) in the cell culture medium, polyplexes may aggregate and become bigger right after their addition to the well. This results in greater transfection efficiencies because larger complexes settle and interact faster with cells $[46,68,122]$.
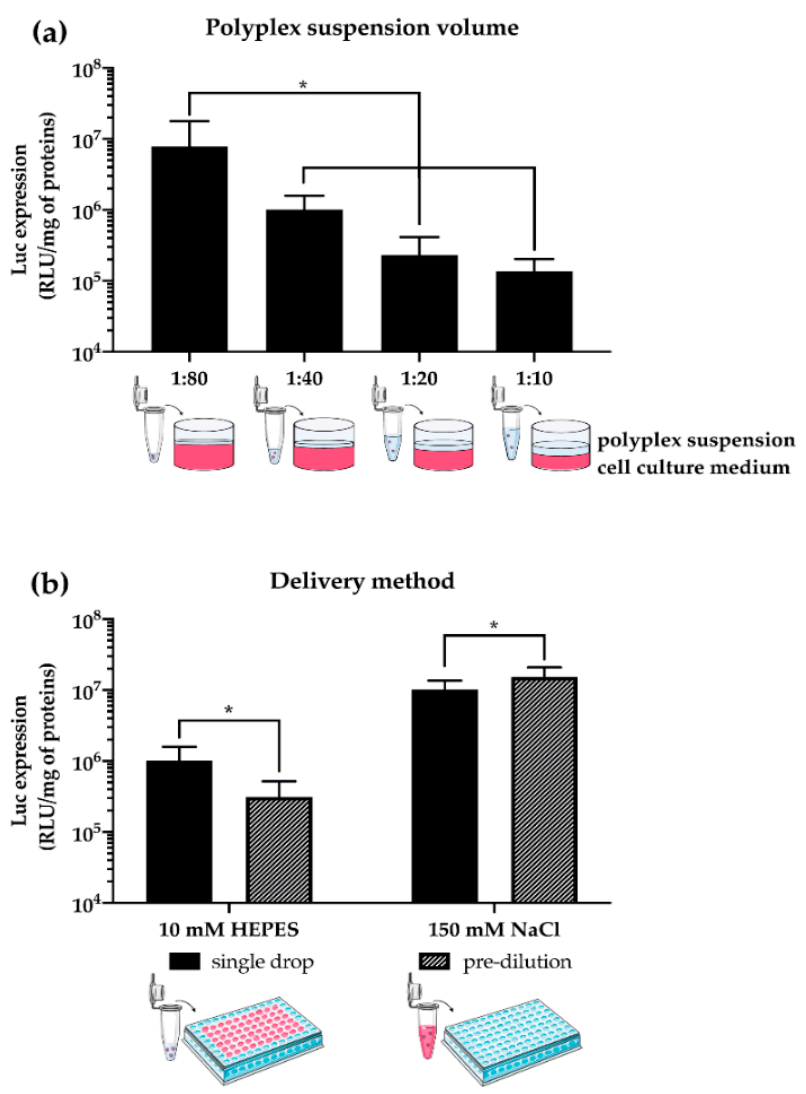

Figure 6. Effect of the volume of polyplex suspension and the delivery method on the transfection efficiency of pDNA/lPEI complexes prepared at N/P 30 in L929 cells. (a) Transfection efficiency of $\mathrm{pDNA} / \mathrm{PEI}$ complexes as a function of the polyplex volume:medium volume ratio. Complexes were prepared by mixing $160 \mathrm{ng} / \mathrm{cm}^{2}$ of pGL3 with $l$ PEI solutions prepared in $10 \mathrm{mM}$ Hepes in a final transfection volume of $1.28,2.5,5.12$, and $10 \mu \mathrm{L}$, corresponding to $1: 80,1: 40,1: 20$, and $1: 10(v / v)$ ratios, respectively. The final volume of cell culture medium was $100 \mu \mathrm{L} /$ well. (b) Transfection efficiency of pDNA/lPEI complexes as a function of the delivery method. Complexes were prepared by mixing 160 $\mathrm{ng} / \mathrm{cm}^{2}$ of pGL3 with the $l \mathrm{PEI}$ in $10 \mathrm{mM}$ Hepes in a final transfection volume of $2.56 \mu \mathrm{L} /$ well and (i) directly added to culture medium in every well (i.e., single drop) or (ii) pre-diluted in the cell culture medium and next added to every well (i.e., pre-dilution). Results are expressed as mean $\pm \operatorname{SD}(n \geq 3)$ ( $^{*}$ $p<0.05)$.

Yet, the way polyplexes are added to cells may also dramatically affect the transfection efficiency. By and large, the delivery of complexes to cells is obtained through the addition of the transfection suspension to the cells cultured in the culture medium [62,96], or the culture vessel in which the cells were plated is emptied, polyplexes are first pre-diluted in the culture medium and then added to the cells $[57,64]$. As a general observation, $l$ PEI-polyplexes prepared in $10 \mathrm{mM}$ Hepes have smaller $\mathrm{D}_{\mathrm{H}}$ and are more effective when directly added to the transfection well, while bigger particles (e.g., those prepared in $150 \mathrm{mM} \mathrm{NaCl}$ ) benefit from the pre-dilution step in cell culture medium before they are incubated with cells (Figure 6b).

In overall terms, we herein point to the way complexes are prepared (e.g., the complexation buffer used) and the way polyplexes are delivered to cells as means to fine-tune the transfection effectiveness 
of a gene delivery vector. Because they are seldom considered as worthy, but their impact is huge, such details should be thoroughly described in any work on this matter.

\subsection{Evaluation of Transfection Effectiveness: A Trade-off Between Transfection Efficiency and Cytotoxicity}

One issue concerning the in vitro screening of transfectants pertains to the assays used to assess gene delivery efficacy. The effectiveness of non-viral vectors is causally linked to their ability to cross the cellular membrane and release the genetic cargo to allow transgene expression $[46,70,155]$. Quantitative and correlative measurements are therefore used to assess the safety and the efficacy of the delivery technologies [156-158].

Transfection efficiency is typically evaluated by analyzing the expression of a luminescent protein (i.e., firefly luciferase [62]), a fluorescent protein (i.e., GFP [159]), or other easily detectable proteins such as the $\beta$-galactosidase [137], or a combination thereof [160]. Depending on the transgene delivered, the read-out system allows direct detection of the cells expressing the protein of interest, as for fluorescent proteins, through flow cytometry (FCM) and imaging techniques, or indirectly [68,137]. The latter relies on collecting the chemiluminescence signal arising from the enzymatic conversion of a substrate into a product, as in the case of luciferase. Albeit these reporter genes are often used interchangeably in transfection experiments, each transgene and respective assay has a different sensitivity and its own metrics [161]. For instance, fluorescent proteins are good descriptors of the transfection efficiency at the single cells level, which is typically defined as the percentage of cells expressing the transgene-encoded protein [162-164]. Conversely, luciferase expression provides relevant information about pDNA expression levels within a cell population but not in single cells, as the chemiluminescence is expressed as arbitrary luminescence units per milligram of proteins in cell lysates [165-168]. Accordingly, each of these metrics is not, unfortunately, a comprehensive estimator of the efficiency of a given transfectant, if considered individually. In this regard, van Gaal and co-workers showed how different transgenes and read-out systems may reveal differences in the onset, level, and peak of expression [137].

Hence, it follows that the assessment of the transfection efficiency of a given transfectant by means of at least two different transgenes and read-out technologies allows a deeper and wider characterization of its gene delivery performance.

The other side of the coin is the toxicity related to the gene delivery system. As a rule of thumb, the higher the transfection efficiency, the greater the cytotoxicity of a given gene delivery vector $[169,170]$, and PEIs are not an exception. Contrary to popular belief, PEI is typically used in transfection experiments in vitro at concentrations far below the toxicity threshold, as depicted in Figures S1, S2, S4, and S5.

The toxicity induced by non-viral gene delivery vectors and assemblies is generally assessed by means of colorimetric commercial test kits, such as Alamar Blue ${ }^{\circledR}$, MTT, and XTT $[117,152,153,171]$. These cell viability assays make use of oxidation-reduction indicators that undergo a color change in response to the cellular metabolic reduction so that one can get quantitative information on the viability of transfected cells. Of note, gene delivery vectors are chemicals and, as such, they may interfere with colorimetric assays that thus provide faulty data [172-174]. Besides, lactate dehydrogenase (LDH), a method used to evaluate the cell toxicity by measuring the activity of cytoplasmic enzymes released by damaged cells, and live-dead staining coupled to FCM, are sometimes used as well.

Overall, a broad spectrum of cell viability/cytotoxicity assays is currently used in the field of non-viral gene delivery. The selection of the appropriate method among those available is important for obtaining accurate and reliable results. When selecting the cytotoxicity and cell viability assays to be used in the study, different parameters have to be considered, such as test compounds, detection mechanisms, specificity, and sensitivity.

\section{Conclusions}

The best way to compare the overall effectiveness in vitro of new gene delivery vectors between laboratories is to gauge their performances with respect to those of suitable benchmarks of seemingly 
well-known behavior. PEIs, together with commercially available reagents and kits such as those belonging to the Lipofectamine series and jetPEI ${ }^{\circledR}$, have largely been used in a number of studies in this regard $[57,60,69,175-178]$. The way any benchmark transfectant behaves and performs is, however, critically dependent on a variety of parameters and in-home experimental conditions. Herein above, we sought to provide a catalog of relevant transfection conditions that were found optimal for the gold standard and internal reference, $25 \mathrm{kDa} l \mathrm{PEI}$, and which can be profitably replicated across in vitro studies for the sake of comparison. Because there is no good science in bad models, it is our truthful hope that this review may provide fertile ground for the implementation of standardized protocols for an unbiased evaluation of the transfection effectiveness in vitro of more and more effective gene delivery reagents, and help scientists advance their work at a much faster pace.

Supplementary Materials: The following are available online at http://www.mdpi.com/1999-4923/12/2/183/s1, S1. Experimental section; S2. Results; Figure S1: Cytotoxicity of complexes prepared at different N/P ratio; Figure S2: Cytotoxicity of pDNA/lPEI complexes prepared in different buffers; Figure S3: Effect of the complexation method on the physico-chemical characteristics of pDNA/IPEI complexes; Figure S4: Cytotoxicity of pDNA/lPEI complexes on L929 cells as a function of the complexation method; Figure S5: Cytotoxicity of pDNA/lPEI complexes on L929 cells as a function of the cell culture volume ratio and delivery method; Table S1: Physico-chemical characteristics of complexes prepared in different buffers; S3. References.

Author Contributions: Conceptualization, supervision, and resources, G.C; investigation, formal analysis, and data curation, N.B. and F.P.; methodology, N.B., F.P. and G.C.; writing-original draft preparation, N.B., F.P., D.M. and G.C.; writing-review and editing, N.B., F.P., D.M. and G.C. All authors have read and agreed to the published version of the manuscript.

Funding: This research received no external funding.

Acknowledgments: We wish to thank Paolo Tarsini (Politecnico di Milano) for the preparation of materials and reagents used for experiments.

Conflicts of Interest: The authors declare no conflict of interest.

\section{References}

1. Lostalé-Seijo, I.; Montenegro, J. Synthetic materials at the forefront of gene delivery. Nat. Rev. Chem. 2018, 2, 258-277. [CrossRef]

2. Wirth, T.; Parker, N.; Ylä-Herttuala, S. History of gene therapy. Gene 2013, 525, 162-169. [CrossRef]

3. Pan, J.; Zhang, S.; Chen, C.; Xiao, S.; Sun, Y.; Liu, C.; Su, X.; Li, D.; Xu, G.; Xu, B.; et al. Effect of recombinant adenovirus-p53 combined with radiotherapy on long-term prognosis of advanced nasopharyngeal carcinoma. J. Clin. Oncol. 2009, 27, 799-804. [CrossRef]

4. Aied, A.; Greiser, U.; Pandit, A.; Wang, W. Polymer gene delivery: Overcoming the obstacles. Drug Discov. Today 2013, 18, 1090-1098. [CrossRef]

5. Baldi, L.; Hacker, D.L.; Adam, M.; Wurm, F.M. Recombinant protein production by large-scale transient gene expression in mammalian cells: State of the art and future perspectives. Biotechnol. Lett. 2007, 29, 677-684. [CrossRef] [PubMed]

6. Pham, P.L.; Kamen, A.; Durocher, Y. Large-scale transfection of mammalian cells for the fast production of recombinant protein. Mol. Biotechnol. 2006, 34, 225-237. [CrossRef]

7. Bandaranayake, A.D.; Almo, S.C. Recent advances in mammalian protein production. FEBS Lett. 2014, 588, 253-260. [CrossRef]

8. Wong, J.K.L.; Mohseni, R.; Hamidieh, A.A.; MacLaren, R.E.; Habib, N.; Seifalian, A.M. Will Nanotechnology Bring New Hope for Gene Delivery? Trends Biotechnol. 2017, 35, 434-451. [CrossRef]

9. Lächelt, U.; Wagner, E. Nucleic Acid Therapeutics Using Polyplexes: A Journey of 50 Years (and Beyond). Chem. Rev. 2015, 115, 11043-11078. [CrossRef]

10. Rinaldi, C.; Wood, M.J.A. Antisense oligonucleotides: The next frontier for treatment of neurological disorders. Nat. Rev. Neurol. 2018, 14, 9-22. [CrossRef] [PubMed]

11. Pezzoli, D.; Chiesa, R.; De Nardo, L.; Candiani, G. We still have a long way to go to effectively deliver genes! J. Appl. Biomater. Funct. Mater. 2012, 10, 82-91. [CrossRef] [PubMed] 
12. Pezzoli, D.; Candiani, G. Non-viral gene delivery strategies for gene therapy: A "ménage à trois" among nucleic acids, materials, and the biological environment: Stimuli-responsive gene delivery vectors. J. Nanoparticle Res. 2013, 15, 1523.

13. Thiel, C.; Nix, M. Efficient transfection of primary cells relevant for cardiovascular research by nucleofection. Methods Mol. Med. 2006, 129, 255-266. [PubMed]

14. Lin, Y.C.; Li, M.; Wu, C.C. Simulation and experimental demonstration of the electric field assisted electroporation microchip for in vitro gene delivery enhancement. Lab Chip 2004, 4, 104-108. [CrossRef]

15. Iversen, N.; Birkenes, B.; Torsdalen, K.; Djurovic, S. Electroporation by nucleofactor is the best nonviral transfection technique in human endothelial and smooth muscle cells. Genet. Vaccines Ther. 2005, 3. [CrossRef]

16. Liao, Z.K.; Tsai, K.C.; Wang, H.T.; Tseng, S.H.; Deng, W.P.; Chen, W.S.; Hwang, L.H. Sonoporation-mediated anti-angiogenic gene transfer into muscle effectively regresses distant orthotopic tumors. Cancer Gene Ther. 2012, 19, 171-180. [CrossRef]

17. Li, Y.S.; Davidson, E.; Reid, C.N.; McHale, A.P. Optimising ultrasound-mediated gene transfer (sonoporation) in vitro and prolonged expression of a transgene in vivo: Potential applications for gene therapy of cancer. Cancer Lett. 2009, 273, 62-69. [CrossRef]

18. Mignet, N.; Marie, C.; Delalande, A.; Manta, S.; Bureau, M.F.; Renault, G.; Scherman, D.; Pichon, C. Microbubbles for nucleic acid delivery in liver using mild sonoporation. In Methods in Molecular Biology; Humana Press Inc.: Totowa, NJ, USA, 2019; Volume 1943, pp. 377-387.

19. Scherer, F.; Anton, M.; Schillinger, U.; Henke, J.; Bergemann, C.; Krüger, A.; Gänsbacher, B.; Plank, C. Magnetofection: Enhancing and targeting gene delivery by magnetic force in vitro and in vivo. Gene Ther. 2002, 9, 102-109. [CrossRef]

20. Krötz, F.; Sohn, H.-Y.; Gloe, T.; Plank, C.; Pohl, U. Magnetofection Potentiates Gene Delivery to Cultured Endothelial Cells. J. Vasc. Res. 2003, 40, 425-434. [CrossRef]

21. Davis, A.A.; Farrar, M.J.; Nishimura, N.; Jin, M.M.; Schaffer, C.B. Optoporation and genetic manipulation of cells using femtosecond laser pulses. Biophys. J. 2013, 105, 862-871. [CrossRef]

22. Schneckenburger, H.; Hendinger, A.; Sailer, R.; Strauss, W.S.L.; Schmitt, M. Laser-assisted optoporation of single cells. J. Biomed. Opt. 2002, 7, 410. [CrossRef]

23. O'Brien, J.A.; Lummis, S.C.R. Biolistic transfection of neuronal cultures using a hand-held gene gun. Nat. Protoc. 2006, 1, 977-981. [CrossRef] [PubMed]

24. Chow, Y.T.; Chen, S.; Wang, R.; Liu, C.; Kong, C.W.; Li, R.A.; Cheng, S.H.; Sun, D. Single cell transfection through precise microinjection with quantitatively controlled injection volumes. Sci. Rep. 2016, 6. [CrossRef] [PubMed]

25. King, R. Gene delivery to mammalian cells by microinjection. Methods Mol. Biol. 2004, 245, 167-174. [PubMed]

26. Chenuet, S.; Derouazi, M.; Hacker, D.; Wurm, F. DNA delivery by microinjection for the generation of recombinant mammalian cell lines. Methods Mol. Biol. 2009, 518, 99-112.

27. Mehier-Humbert, S.; Guy, R.H. Physical methods for gene transfer: Improving the kinetics of gene delivery into cells. Adv. Drug Deliv. Rev. 2005, 57, 733-753. [CrossRef]

28. Du, X.; Wang, J.; Zhou, Q.; Zhang, L.; Wang, S.; Zhang, Z.; Yao, C. Advanced physical techniques for gene delivery based on membrane perforation. Drug Deliv. 2018, 25, 1516-1525. [CrossRef]

29. Mellott, A.J.; Forrest, M.L.; Detamore, M.S. Physical non-viral gene delivery methods for tissue engineering. Ann. Biomed. Eng. 2013, 41, 446-468. [CrossRef]

30. Lungwitz, U.; Breunig, M.; Blunk, T.; Göpferich, A. Polyethylenimine-based non-viral gene delivery systems. Eur. J. Pharm. Biopharm. 2005, 60, 247-266.

31. Ogris, M.; Wagner, E. Targeting tumors with non-viral gene delivery systems. Drug Discov. Today 2002, 7, 479-485. [CrossRef]

32. Tomlinson, E.; Rolland, A.P. Controllable gene therapy pharmaceutics of non-viral gene delivery systems. J. Control. Release 1996, 39, 357-372. [CrossRef]

33. De Laporte, L.; Cruz Rea, J.; Shea, L.D. Design of modular non-viral gene therapy vectors. Biomaterials 2006, 27, 947-954. [CrossRef] [PubMed]

34. Finer, M.; Glorioso, J. A brief account of viral vectors and their promise for gene therapy. Gene Ther. 2017, 24, 1-2. [CrossRef] 
35. Keeler, A.M.; ElMallah, M.K.; Flotte, T.R. Gene Therapy 2017: Progress and Future Directions. Clin. Transl. Sci. 2017, 10, 242-248. [CrossRef] [PubMed]

36. Ginn, S.L.; Amaya, A.K.; Alexander, I.E.; Edelstein, M.; Abedi, M.R. Gene therapy clinical trials worldwide to 2017: An update. J. Gene Med. 2018, 20, e3015. [CrossRef] [PubMed]

37. van der Loo, J.C.M.; Wright, J.F. Progress and challenges in viral vector manufacturing. Hum. Mol. Genet. 2016, 25, R42-R52. [CrossRef]

38. Kotterman, M.A.; Chalberg, T.W.; Schaffer, D.V. Viral Vectors for Gene Therapy: Translational and Clinical Outlook. Annu. Rev. Biomed. Eng. 2015, 17, 63-89. [CrossRef]

39. Thomas, C.E.; Ehrhardt, A.; Kay, M.A. Progress and problems with the use of viral vectors for gene therapy. Nat. Rev. Genet. 2003, 4, 346-358. [CrossRef]

40. Nayerossadat, N.; Ali, P.; Maedeh, T. Viral and nonviral delivery systems for gene delivery. Adv. Biomed. Res. 2012, 1, 27. [CrossRef]

41. Sung, Y.K.; Kim, S.W. Recent advances in the development of gene delivery systems. Biomater. Res. $2019,23$. [CrossRef]

42. Jinturkar, K.A.; Rathi, M.N.; Misra, A. Gene Delivery Using Physical Methods. In Challenges in Delivery of Therapeutic Genomics and Proteomics; Elsevier: Amsterdan, The Netherlands, 2011; pp. 83-126.

43. Lundstrom, K. Viral Vectors in Gene Therapy. Diseases 2018, 6, 42. [CrossRef]

44. Milone, M.C.; O’Doherty, U. Clinical use of lentiviral vectors. Leukemia 2018, 32, 1529-1541. [CrossRef] [PubMed]

45. Park, T.G.; Jeong, J.H.; Kim, S.W. Current status of polymeric gene delivery systems. Adv. Drug Deliv. Rev. 2006, 58, 467-486. [CrossRef] [PubMed]

46. Jones, C.H.; Chen, C.K.; Ravikrishnan, A.; Rane, S.; Pfeifer, B.A. Overcoming nonviral gene delivery barriers: Perspective and future. Mol. Pharm. 2013, 10, 4082-4098. [CrossRef] [PubMed]

47. Dizaj, S.; Jafari, S.; Khosroushahi, A. A sight on the current nanoparticle-based gene delivery vectors. Nanoscale Res. Lett. 2014, 9, 252. [CrossRef] [PubMed]

48. Levingstone, T.J.; Herbaj, S.; Redmond, J.; McCarthy, H.O.; Dunne, N.J. Calcium Phosphate Nanoparticles-Based Systems for RNAi Delivery: Applications in Bone Tissue Regeneration. Nanomaterials 2020, 10, 146. [CrossRef] [PubMed]

49. Graham, F.L.; van der Eb, A.J. A new technique for the assay of infectivity of human adenovirus 5 DNA. Virology 1973, 52, 456-467. [CrossRef]

50. Wang, W.; Li, W.; Ma, N.; Steinhoff, G. Non-Viral Gene Delivery Methods. Curr. Pharm. Biotechnol. 2013, 14, 46-60.

51. Thapa, B.; Narain, R. Mechanism, current challenges and new approaches for non viral gene delivery. In Polymers and Nanomaterials for Gene Therapy; Woodhead Publishing: Cambridge, UK, 2016; ISBN 9780081005217.

52. Patil; Gao; Lin; Li; Dang; Tian; Zhang; Jiang; Qadir; Qian The Development of Functional Non-Viral Vectors for Gene Delivery. Int. J. Mol. Sci. 2019, 20, 5491. [CrossRef]

53. Godbey, W.T.; Mikos, A.G. Recent progress in gene delivery using non-viral transfer complexes. J. Control. Release 2001, 72, 115-125. [CrossRef]

54. Davis, M.E. Non-viral gene delivery systems. Curr. Opin. Biotechnol. 2002, 13, 128-131. [CrossRef]

55. Bonetta, L. The inside scoop - Evaluating gene delivery methods. Nat. Methods 2005, 2, 875-882. [CrossRef]

56. Felgner, P.L.; Gadek, T.R.; Holm, M.; Roman, R.; Chan, H.W.; Wenz, M.; Northrop, J.P.; Ringold, G.M.; Danielsen, M. Lipofection: A highly efficient, lipid-mediated DNA-transfection procedure. Proc. Natl. Acad. Sci. USA 1987, 84, 7413-7417. [CrossRef]

57. Bono, N.; Pennetta, C.; Sganappa, A.; Giupponi, E.; Sansone, F.; Volonterio, A.; Candiani, G. Design and synthesis of biologically active cationic amphiphiles built on the calix[4]arene scaffold. Int. J. Pharm. 2018, 549, 436-445. [CrossRef]

58. Hoekstra, D.; Rejman, J.; Wasungu, L.; Shi, F.; Zuhorn, I. Gene delivery by cationic lipids: In and out of an endosome. Biochem. Soc. Trans. 2007, 35, 68-71. [CrossRef]

59. Simões, S.; Filipe, A.; Faneca, H.; Mano, M.; Penacho, N.; Düzgünes, N.; de Lima, M.P. Cationic liposomes for gene delivery. Expert Opin. Drug Deliv. 2005, 2, 237-254. [CrossRef] [PubMed]

60. Candiani, G.; Pezzoli, D.; Ciani, L.; Chiesa, R.; Ristori, S. Bioreducible liposomes for gene delivery: From the formulation to the mechanism of action. PLoS One 2010, 5. [CrossRef] [PubMed] 
61. Pezzoli, D.; Kajaste-Rudnitski, A.; Chiesa, R.; Candiani, G. Lipid-based nanoparticles as nonviral gene delivery vectors. Methods Mol. Biol. 2013, 1025, 269-279. [PubMed]

62. Malloggi, C.; Pezzoli, D.; Magagnin, L.; De Nardo, L.; Mantovani, D.; Tallarita, E.; Candiani, G. Comparative evaluation and optimization of off-the-shelf cationic polymers for gene delivery purposes. Polym. Chem. 2015, 6, 6325-6339. [CrossRef]

63. Pezzoli, D.; Tsekoura, E.K.; Remant Bahadur, K.C.; Candiani, G.; Mantovani, D.; Uludağ, H. Hydrophobe-substituted bPEI derivatives: Boosting transfection on primary vascular cells. Sci. China Mater. 2017, 60, 529-542. [CrossRef]

64. Bono, N.; Pennetta, C.; Bellucci, M.C.; Sganappa, A.; Malloggi, C.; Tedeschi, G.; Candiani, G.; Volonterio, A. Role of Generation on Successful DNA Delivery of PAMAM-(Guanidino)Neomycin Conjugates. ACS Omega 2019, 4, 6796-6807. [CrossRef]

65. Boussif, O.; Lezoualc'h, F.; Zanta, M.A.; Mergny, M.D.; Scherman, D.; Demeneix, B.; Behr, J.P. A versatile vector for gene and oligonucleotide transfer into cells in culture and in vivo: Polyethylenimine. Proc. Natl. Acad. Sci. 1995, 92, 7297-7301. [CrossRef]

66. Von Harpe, A.; Petersen, H.; Li, Y.; Kissel, T. Characterization of commercially available and synthesized polyethylenimines for gene delivery. J. Control. Release 2000, 69, 309-322. [CrossRef]

67. Xu, Q.; Wang, C.-H.; Wayne Pack, D. Polymeric Carriers for Gene Delivery: Chitosan and Poly(amidoamine) Dendrimers. Curr. Pharm. Des. 2010, 16, 2350-2368. [CrossRef] [PubMed]

68. Hill, A.B.; Chen, M.; Chen, C.K.; Pfeifer, B.A.; Jones, C.H. Overcoming gene-delivery hurdles: Physiological considerations for nonviral vectors. Trends Biotechnol. 2016, 34, 91-105. [CrossRef] [PubMed]

69. Mintzer, M.A.; Simanek, E.E. Nonviral vectors for gene delivery. Chem. Rev. 2009, 109, 259-302. [CrossRef]

70. Gigante, A.; Li, M.; Junghänel, S.; Hirschhäuser, C.; Knauer, S.; Schmuck, C. Non-viral transfection vectors: Are hybrid materials the way forward? Medchemcomm 2019, 10, 1692-1718.

71. Slivac, I.; Guay, D.; Mangion, M.; Champeil, J.; Gaillet, B. Non-viral nucleic acid delivery methods. Expert Opin. Biol. Ther. 2017, 17, 105-118. [CrossRef] [PubMed]

72. Bespalov, A.; Steckler, T. Lacking quality in research: Is behavioral neuroscience affected more than other areas of biomedical science? J. Neurosci. Methods 2018, 300, 4-9. [CrossRef]

73. Brazma, A.; Hingamp, P.; Quackenbush, J.; Sherlock, G.; Spellman, P.; Stoeckert, C.; Aach, J.; Ansorge, W.; Ball, C.A.; Causton, H.C.; et al. Minimum information about a microarray experiment (MIAME) - Toward standards for microarray data. Nat. Genet. 2001, 29, 365-371. [CrossRef] [PubMed]

74. Le Novère, N.; Finney, A.; Hucka, M.; Bhalla, U.S.; Campagne, F.; Collado-Vides, J.; Crampin, E.J.; Halstead, M.; Klipp, E.; Mendes, P.; et al. Minimum information requested in the annotation of biochemical models (MIRIAM). Nat. Biotechnol. 2005, 23, 1509-1515. [CrossRef]

75. Taylor, C.F.; Field, D.; Sansone, S.A.; Aerts, J.; Apweiler, R.; Ashburner, M.; Ball, C.A.; Binz, P.A.; Bogue, M.; Booth, T.; et al. Promoting coherent minimum reporting guidelines for biological and biomedical investigations: The MIBBI project. Nat. Biotechnol. 2008, 26, 889-896. [CrossRef] [PubMed]

76. Faria, M.; Björnmalm, M.; Thurecht, K.J.; Kent, S.J.; Parton, R.G.; Kavallaris, M.; Johnston, A.P.R.; Gooding, J.J.; Corrie, S.R.; Boyd, B.J.; et al. Minimum information reporting in bio-nano experimental literature. Nat. Nanotechnol. 2018, 13, 777-785. [CrossRef] [PubMed]

77. Hsu, C.; Uludağ, H. Effects of size and topology of DNA molecules on intracellular delivery with non-viral gene carriers. BMC Biotechnol. 2008, 8, 23. [CrossRef] [PubMed]

78. Remaut, K.; Symens, N.; Lucas, B.; Demeester, J.; De Smedt, S.C. Cell division responsive peptides for optimized plasmid DNA delivery: The mitotic window of opportunity? J. Control. Release 2014, 179, 1-9. [CrossRef]

79. Cherng, J.Y.; Schuurmans-Nieuwenbroek, N.M.E.; Jiskoot, W.; Talsma, H.; Zuidam, N.J.; Hennink, W.E.; Crommelin, D.J.A. Effect of DNA topology on the transfection efficiency of poly((2-dimethylamino)ethyl methacrylate)-plasmid complexes. J. Control. Release 1999, 60, 343-353. [CrossRef]

80. Weintraub, H.; Cheng, P.F.; Conrad, K. Expression of transfected DNA depends on DNA topology. Cell 1986, 46, 115-122. [CrossRef]

81. Tudini, E.; Burke, L.J.; Whiley, P.J.; Sevcik, J.; Spurdle, A.B.; Brown, M.A. Caution: Plasmid DNA topology affects luciferase assay reproducibility and outcomes. Biotechniques 2019, 67, 94-96. [CrossRef]

82. Mairhofer, J.; Grabherr, R. Rational vector design for efficient non-viral gene delivery: Challenges facing the use of plasmid DNA. Mol. Biotechnol. 2008, 39, 97-104. [CrossRef] 
83. Kreiss, P.; Cameron, B.; Rangara, R.; Mailhe, P.; Aguerre-Charriol, O.; Airiau, M.; Scherman, D.; Crouzet, J.; Pitard, B. Plasmid DNA size does not affect the physicochemical properties of lipoplexes but modulates gene transfer efficiency. Nucleic Acids Res. 1999, 27, 3792-3798. [CrossRef]

84. Shaimardanova, A.A.; Kitaeva, K.V.; Abdrakhmanova, I.I.; Chernov, V.M.; Rutland, C.S.; Rizvanov, A.A.; Chulpanova, D.S.; Solovyeva, V.V. Production and application of multicistronic constructs for various human disease therapies. Pharmaceutics 2019, 11, 580. [CrossRef]

85. Chan, K.K.-K.; Wu, S.M.; Nissom, P.M.; Oh, S.K.W.; Choo, A.B.H. Generation of high-level stable transgene expressing human embryonic stem cell lines using Chinese hamster elongation factor-1 alpha promoter system. Stem Cells Dev. 2008, 17, 825-836. [CrossRef] [PubMed]

86. Tokushige, K.; Moradpour, D.; Wakita, T.; Geissler, M.; Hayashi, N.; Wands, J.R. Comparison between cytomegalovirus promoter and elongation factor-1 alpha promoter-driven constructs in the establishment of cell lines expressing hepatitis C virus core protein. J. Virol. Methods 1997, 64, 73-80. [CrossRef]

87. Gopalkrishnan, R. Use of the human EF-1alpha promoter for expression can significantly increase success in establishing stable cell lines with consistent expression: A study using the tetracycline-inducible system in human cancer cells. Nucleic Acids Res. 1999, 27, 4775-4782. [CrossRef]

88. Raup, A.; Jérôme, V.; Freitag, R.; Synatschke, C.V.; Müller, A.H.E. Promoter, transgene, and cell line effects in the transfection of mammalian cells using PDMAEMA-based nano-stars. Biotechnol. Reports 2016, 11, 53-61. [CrossRef]

89. Chung, S.; Andersson, T.; Sonntag, K.-C.; Björklund, L.; Isacson, O.; Kim, K.-S. Analysis of Different Promoter Systems for Efficient Transgene Expression in Mouse Embryonic Stem Cell Lines. Stem Cells 2002, 20, 139-145. [CrossRef]

90. Irobalieva, R.N.; Fogg, J.M.; Catanese, D.J.; Sutthibutpong, T.; Chen, M.; Barker, A.K.; Ludtke, S.J.; Harris, S.A.; Schmid, M.F.; Chiu, W.; et al. Structural diversity of supercoiled DNA. Nat. Commun. 2015, 6, 8440. [CrossRef]

91. Peng, L.; Wagner, E. Polymeric Carriers for Nucleic Acid Delivery: Current Designs and Future Directions. Biomacromolecules 2019, 20, 3613-3626. [CrossRef]

92. Lai, W.F.; Wong, W.T. Design of Polymeric Gene Carriers for Effective Intracellular Delivery. Trends Biotechnol. 2018, 36, 713-728. [CrossRef]

93. Wightman, L.; Kircheis, R.; Wagner, E. Polymer-Based gene delivery systems. In Pharmaceutical Gene Delivery Systems; CRC Press: Boca Raton, FL, USA, 2003; pp. 109-135. ISBN 9780203912331.

94. Zhang, X.; Oulad-Abdelghani, M.; Zelkin, A.N.; Wang, Y.; Haîkel, Y.; Mainard, D.; Voegel, J.-C.; Caruso, F.; Benkirane-Jessel, N. Poly(L-lysine) nanostructured particles for gene delivery and hormone stimulation. Biomaterials 2010, 31, 1699-1706. [CrossRef]

95. Mandal, H.; Katiyar, S.S.; Swami, R.; Kushwah, V.; Katare, P.B.; Kumar Meka, A.; Banerjee, S.K.; Popat, A.; Jain, S. $\varepsilon$-Poly-l-Lysine/plasmid DNA nanoplexes for efficient gene delivery in vivo. Int. J. Pharm. 2018, 542, 142-152. [CrossRef]

96. Pezzoli, D.; Giupponi, E.; Mantovani, D.; Candiani, G. Size matters for in vitro gene delivery: Investigating the relationships among complexation protocol, transfection medium, size and sedimentation. Sci. Rep. 2017, 7, 44134. [CrossRef] [PubMed]

97. Zakeri, A.; Kouhbanani, M.A.J.; Beheshtkhoo, N.; Beigi, V.; Mousavi, S.M.; Hashemi, S.A.R.; Karimi Zade, A.; Amani, A.M.; Savardashtaki, A.; Mirzaei, E.; et al. Polyethylenimine-based nanocarriers in co-delivery of drug and gene: A developing horizon. Nano Rev. Exp. 2018, 9, 1488497. [CrossRef] [PubMed]

98. Chen, K.; Xin, X.; Qiu, L.; Li, W.; Guan, G.; Li, G.; Qiao, M.; Zhao, X.; Hu, H.; Chen, D. Co-delivery of p53 and MDM2 inhibitor RG7388 using a hydroxyl terminal PAMAM dendrimer derivative for synergistic cancer therapy. Acta Biomater. 2019, 100, 118-131. [CrossRef]

99. Ghilardi, A.; Pezzoli, D.; Bellucci, M.C.; Malloggi, C.; Negri, A.; Sganappa, A.; Tedeschi, G.; Candiani, G.; Volonterio, A. Synthesis of multifunctional PAMAM-aminoglycoside conjugates with enhanced transfection efficiency. Bioconjug. Chem. 2013, 24, 1928-1936. [CrossRef]

100. Dong, Y.; Yu, T.; Ding, L.; Laurini, E.; Huang, Y.; Zhang, M.; Weng, Y.; Lin, S.; Chen, P.; Marson, D.; et al. A Dual Targeting Dendrimer-Mediated siRNA Delivery System for Effective Gene Silencing in Cancer Therapy. J. Am. Chem. Soc. 2018, 140, 16264-16274. [CrossRef]

101. Chen, C.; Posocco, P.; Liu, X.; Cheng, Q.; Laurini, E.; Zhou, J.; Liu, C.; Wang, Y.; Tang, J.; Col, V.D.; et al. Mastering Dendrimer Self-Assembly for Efficient siRNA Delivery: From Conceptual Design to In Vivo Efficient Gene Silencing. Small 2016, 12, 3667-3676. [CrossRef] 
102. Agarwal, S.; Zhang, Y.; Maji, S.; Greiner, A. PDMAEMA based gene delivery materials. Mater. Today 2012, 15, 388-393. [CrossRef]

103. Köping-Höggård, M.; Vårum, K.M.; Issa, M.; Danielsen, S.; Christensen, B.E.; Stokke, B.T.; Artursson, P. Improved chitosan-mediated gene delivery based on easily dissociated chitosan polyplexes of highly defined chitosan oligomers. Gene Ther. 2004, 11, 1441-1452. [CrossRef] [PubMed]

104. Chuan, D.; Jin, T.; Fan, R.; Zhou, L.; Guo, G. Chitosan for gene delivery: Methods for improvement and applications. Adv. Colloid Interface Sci. 2019, 268, 25-38. [CrossRef]

105. Strand, S.P.; Lelu, S.; Reitan, N.K.; de Lange Davies, C.; Artursson, P.; Vårum, K.M. Molecular design of chitosan gene delivery systems with an optimized balance between polyplex stability and polyplex unpacking. Biomaterials 2010, 31, 975-987. [CrossRef]

106. Rahmani, S.; Hakimi, S.; Esmaeily, A.; Samadi, F.Y.; Mortazavian, E.; Nazari, M.; Mohammadi, Z.; Tehrani, N.R.; Tehrani, M.R. Novel chitosan based nanoparticles as gene delivery systems to cancerous and noncancerous cells. Int. J. Pharm. 2019, 560, 306-314. [CrossRef] [PubMed]

107. Chen, H.; Cui, S.; Zhao, Y.; Zhang, C.; Zhang, S.; Peng, X. Grafting chitosan with polyethylenimine in an ionic liquid for efficient gene delivery. PLoS One 2015, 10, e0121817. [CrossRef]

108. Pezzoli, D.; Tarsini, P.; Melone, L.; Candiani, G. RGD-derivatized PEI-PEG copolymers: Influence of the degree of substitution on the targeting behavior. J. Drug Deliv. Sci. Technol. 2017, 37, 115-122. [CrossRef]

109. Bansal, R.; Seth, B.; Tiwari, S.; Jahan, S.; Kumari, M.; Pant, A.B.; Chaturvedi, R.K.; Kumar, P.; Gupta, K.C. Hexadecylated linear PEI self-assembled nanostructures as efficient vectors for neuronal gene delivery. Drug Deliv. Transl. Res. 2018, 8, 1436-1449. [CrossRef] [PubMed]

110. Thapa, B.; Plianwong, S.; Remant Bahadur, K.; Rutherford, B.; Uludağ, H. Small hydrophobe substitution on polyethylenimine for plasmid DNA delivery: Optimal substitution is critical for effective delivery. Acta Biomater. 2016, 33, 213-224. [CrossRef] [PubMed]

111. Pack, D.W.; Hoffman, A.S.; Pun, S.; Stayton, P.S. Design and development of polymers for gene delivery. Nat. Rev. Drug Discov. 2005, 4, 581-593. [CrossRef] [PubMed]

112. Bahadur, K.C.R.; Uludağ, H. PEI and its derivatives for gene therapy. In Polymers and Nanomaterials for Gene Therapy; Elsevier Inc.: Amsterdam, The Netherlands, 2016; ISBN 9780081005217.

113. Dai, Z.; Gjetting, T.; Mattebjerg, M.A.; Wu, C.; Andresen, T.L. Elucidating the interplay between DNA-condensing and free polycations in gene transfection through a mechanistic study of linear and branched PEI. Biomaterials 2011, 32, 8626-8634. [CrossRef] [PubMed]

114. Godbey, W.T.; Wu, K.K.; Mikos, A.G. Size matters: Molecular weight affects the efficiency of poly(ethylenimine) as a gene delivery vehicle. J. Biomed. Mater. Res. 1999, 45, 268-275. [CrossRef]

115. Fischer, D.; Bieber, T.; Li, Y.; Elsässer, H.P.; Kissel, T. A novel non-viral vector for DNA delivery based on low molecular weight, branched polyethylenimine: Effect of molecular weight on transfection efficiency and cytotoxicity. Pharm. Res. 1999, 16, 1273-1279. [CrossRef]

116. Bonner, D.K.; Zhao, X.; Buss, H.; Langer, R.; Hammond, P.T. Crosslinked linear polyethylenimine enhances delivery of DNA to the cytoplasm. J. Control. Release 2013, 167, 101-107. [CrossRef]

117. Yue, Y.; Jin, F.; Deng, R.; Cai, J.; Chen, Y.; Lin, M.C.M.; Kung, H.F.; Wu, C. Revisit complexation between DNA and polyethylenimine - Effect of uncomplexed chains free in the solution mixture on gene transfection. J. Control. Release 2011, 155, 67-76. [CrossRef] [PubMed]

118. Melone, L.; Rossi, B.; Pastori, N.; Panzeri, W.; Mele, A.; Punta, C. TEMPO-Oxidized Cellulose Cross-Linked with Branched Polyethyleneimine: Nanostructured Adsorbent Sponges for Water Remediation. Chempluschem 2015, 80, 1408-1415. [CrossRef] [PubMed]

119. ISO/Guide 30:2015(en), Reference Materials—Selected Terms and Definitions. Available online: https: //www.iso.org/obp/ui/\#iso:std:iso:guide:30:ed-3:v1:en (accessed on 20 January 2020).

120. ISO 17034:2016(en), General Requirements for the Competence of Reference Material Producers. Available online: https://www.iso.org/obp/ui/\#iso:std:iso:17034:ed-1:v1:en (accessed on 20 January 2020).

121. Plant, A.L.; Locascio, L.E.; May, W.E.; Gallagher, P.D. Improved reproducibility by assuring confidence in measurements in biomedical research. Nat. Methods 2014, 11, 895-898. [CrossRef]

122. Ogris, M.; Steinlein, P.; Kursa, M.; Mechtler, K.; Kircheis, R.; Wagner, E. The size of DNA/transferrin-PEI complexes is an important factor for gene expression in cultured cells. Gene Ther. 1998, 5, 1425-1433. [CrossRef] 
123. Zhang, C.; Yadava, P.; Hughes, J. Polyethylenimine strategies for plasmid delivery to brain-derived cells. Methods 2004, 33, 144-150. [CrossRef] [PubMed]

124. Lucotti, A.; Tommasini, M.; Pezzoli, D.; Candiani, G. Molecular interactions of DNA with transfectants: A study based on infrared spectroscopy and quantum chemistry as aids to fluorescence spectroscopy and dynamic light scattering analyses. RSC Adv. 2014, 4, 49620-49627. [CrossRef]

125. Breunig, M.; Lungwitz, U.; Liebl, R.; Klar, J.; Obermayer, B.; Blunk, T.; Goepferich, A. Mechanistic insights into linear polyethylenimine-mediated gene transfer. Biochim. Biophys. Acta - Gen. Subj. 2007, 1770, 196-205. [CrossRef]

126. Breunig, M.; Lungwitz, U.; Liebl, R.; Fontanari, C.; Klar, J.; Kurtz, A.; Blunk, T.; Goepferich, A. Gene delivery with low molecular weight linear polyethylenimines. J. Gene Med. 2005, 7, 1287-1298. [CrossRef]

127. Wiseman, J.W.; Goddard, C.A.; McLelland, D.; Colledge, W.H. A comparison of linear and branched polyethylenimine (PEI) with DCChol/DOPE liposomes for gene delivery to epithelial cells in vitro and in vivo. Gene Ther. 2003, 10, 1654-1662. [CrossRef]

128. Zhang, H.; Chen, Z.; Du, M.; Li, Y.; Chen, Y. Enhanced gene transfection efficiency by low-dose $25 \mathrm{kDa}$ polyethylenimine by the assistance of $1.8 \mathrm{kDa}$ polyethylenimine. Drug Deliv. 2018, 25, 1740-1745. [CrossRef]

129. Wightman, L.; Kircheis, R.; Rössler, V.; Garotta, S.; Ruzicka, R.; Kursa, M.; Wagner, E. Different behavior of branched and linear polyethylenimine for gene delivery in vitro and in vivo. J. Gene Med. 2001, 3, 362-372. [CrossRef] [PubMed]

130. Forest, V.; Pourchez, J. Preferential binding of positive nanoparticles on cell membranes is due to electrostatic interactions: A too simplistic explanation that does not take into account the nanoparticle protein corona. Mater. Sci. Eng. C 2017, 70, 889-896. [CrossRef] [PubMed]

131. Gallops, C.E.; Yu, C.; Ziebarth, J.D.; Wang, Y. Effect of the Protonation Level and Ionic Strength on the Structure of Linear Polyethyleneimine. ACS Omega 2019, 4, 7255-7264. [CrossRef]

132. Lynch, I.; Dawson, K.A. Protein-nanoparticle interactions. Nano Today 2008, 3, 40-47. [CrossRef]

133. Maiolo, D.; Colombo, J.; Beretta, J.; Malloggi, C.; Candiani, G.; Baldelli Bombelli, F. The polyplex, protein corona, cell interplay: Tips and drawbacks. Colloids Surfaces B Biointerfaces 2018, 168, 60-67. [CrossRef] [PubMed]

134. Troiber, C.; Kasper, J.C.; Milani, S.; Scheible, M.; Martin, I.; Schaubhut, F.; Küchler, S.; Rädler, J.; Simmel, F.C.; Friess, W.; et al. Comparison of four different particle sizing methods for siRNA polyplex characterization. Eur. J. Pharm. Biopharm. 2013, 84, 255-264. [CrossRef]

135. Bhattacharjee, S. DLS and zeta potential - What they are and what they are not? J. Control. Release 2016, 235, 337-351. [CrossRef]

136. Bertin, A. Polyelectrolyte complexes of DNA and polycations as gene delivery vectors. Adv. Polym. Sci. 2014, 256, 103-196.

137. Van Gaal, E.V.B.; Van Eijk, R.; Oosting, R.S.; Kok, R.J.; Hennink, W.E.; Crommelin, D.J.A.; Mastrobattista, E. How to screen non-viral gene delivery systems in vitro? J. Control. Release 2011, 154, 218-232. [CrossRef]

138. Wilke, M.; Fortunati, E.; van den Broek, M.; Hoogeveen, A.T.; Scholte, B.J. Efficacy of a peptide-based gene delivery system depends on mitotic activity. Gene Ther. 1996, 3, 1133-1142.

139. Brunner, S.; Sauer, T.; Carotta, S.; Cotten, M.; Saltik, M.; Wagner, E. Cell cycle dependence of gene transfer by lipoplex polyplex and recombinant adenovirus. Gene Ther. 2000, 7, 401-407. [CrossRef] [PubMed]

140. Grellier, M.; Bordenave, L.; Amédée, J. Cell-to-cell communication between osteogenic and endothelial lineages: Implications for tissue engineering. Trends Biotechnol. 2009, 27, 562-571. [CrossRef]

141. Giupponi, E.; Visone, R.; Occhetta, P.; Colombo, F.; Rasponi, M.; Candiani, G. Development of a microfluidic platform for high-throughput screening of non-viral gene delivery vectors. Biotechnol. Bioeng. 2018, 115, 775-784. [CrossRef]

142. Chernov, V.M.; Chernova, O.A.; Sanchez-Vega, J.T.; Kolpakov, A.I.; Ilinskaya, O.N. Mycoplasma contamination of cell cultures: Vesicular traffic in bacteria and control over infectious agents. Acta Naturae 2014, 6, 41-51. [CrossRef]

143. Nikfarjam, L.; Farzaneh, P. Prevention and detection of mycoplasma contamination in cell culture. Cell J. 2012, 13, 203-212. [PubMed]

144. Rottem, S.; Kosower, N.S.; Kornspan, J.D. Contamination of Tissue Cultures by Mycoplasmas. In Biomedical Tissue Culture; InTech: London, UK, 2012. 
145. Yin, Z.; Zhang, Y.; Liang, S.; Zhao, S.; Du, J.; Cheng, B. Mycoplasma contamination-mediated attenuation of plasmid DNA transfection efficiency is augmented via l-arginine deprivation in HEK-293 cells. J. Zhejiang Univ. B 2019, 20, 1021-1026. [CrossRef] [PubMed]

146. Gedye, C.; Cardwell, T.; Dimopoulos, N.; Tan, B.S.; Jackson, H.; Svobodová, S.; Anaka, M.; Behren, A.; Maher, C.; Hofmann, O.; et al. Mycoplasma Infection Alters Cancer Stem Cell Properties in Vitro. Stem Cell Rev. Reports 2016, 12, 156-161. [CrossRef] [PubMed]

147. Freedman, L.P.; Gibson, M.C.; Ethier, S.P.; Soule, H.R.; Neve, R.M.; Reid, Y.A. Reproducibility: Changing the policies and culture of cell line authentication. Nat. Methods 2015, 12, 493-497. [CrossRef] [PubMed]

148. Hopert, A.; Uphoff, C.C.; Wirth, M.; Hauser, H.; Drexler, H.G. Mycoplasma detection by PCR analysis. In Vitro Cell. Dev. Biol. Anim. 1993, 29A, 819-821. [CrossRef]

149. Tang, J.; Hu, M.; Lee, S.; Roblin, R. A polymerase chain reaction based method for detecting Mycoplasma/Acholeplasma contaminants in cell culture. J. Microbiol. Methods 2000, 39, 121-126. [CrossRef]

150. Dobrovolny, P.L.; Bess, D. Optimized PCR-based detection of mycoplasma. J. Vis. Exp. 2011. [CrossRef]

151. Huh, S.H.; Do, H.J.; Lim, H.Y.; Kim, D.K.; Choi, S.J.; Song, H.; Kim, N.H.; Park, J.K.; Chang, W.K.; Chung, H.M.; et al. Optimization of $25 \mathrm{kDa}$ linear polyethylenimine for efficient gene delivery. Biologicals 2007, 35, 165-171. [CrossRef] [PubMed]

152. Deng, R.; Yue, Y.; Jin, F.; Chen, Y.; Kung, H.F.; Lin, M.C.M.; Wu, C. Revisit the complexation of PEI and DNA How to make low cytotoxic and highly efficient PEI gene transfection non-viral vectors with a controllable chain length and structure? J. Control. Release 2009, 140, 40-46. [CrossRef]

153. Tripathi, S.K.; Goyal, R.; Kumar, P.; Gupta, K.C. Linear polyethylenimine-graft-chitosan copolymers as efficient DNA/siRNA delivery vectors in vitro and in vivo. Nanomedicine Nanotechnology, Biol. Med. 2012, 8, 337-345. [CrossRef] [PubMed]

154. Pezzoli, D.; Olimpieri, F.; Malloggi, C.; Bertini, S.; Volonterio, A.; Candiani, G. Chitosan-Graft-Branched Polyethylenimine Copolymers: Influence of Degree of Grafting on Transfection Behavior. PLoS One 2012, 7, e34711. [CrossRef]

155. Nishikawa, M.; Huang, L. Nonviral vectors in the new millennium: Delivery barriers in gene transfer. Hum. Gene Ther. 2001, 12, 861-870. [CrossRef] [PubMed]

156. Faruqui, N.; Kummrow, A.; Fu, B.; Divieto, C.; Rojas, F.; Kisulu, F.; Cavalcante, J.J.V.; Wang, J.; Campbell, J.; Martins, J.L.; et al. Cellular metrology: Scoping for a value proposition in extra-and intracellular measurements. Front. Bioeng. Biotechnol. 2019, 7, 456. [CrossRef]

157. Roth, C.M. Quantitative Measurements and Rational Materials Design for Intracellular Delivery of Oligonucleotides. Biotechnol. Prog. 2008, 24, 23-28. [CrossRef] [PubMed]

158. Varga, C.M.; Hong, K.; Lauffenburger, D.A. Quantitative analysis of synthetic gene delivery vector design properties. Mol. Ther. 2001, 4, 438-446. [CrossRef]

159. Welsh, S.; Kay, S.A. Reporter gene expression for monitoring gene transfer. Curr. Opin. Biotechnol. 1997, 8, 617-622. [CrossRef]

160. Collins, S.; Morrissey, D.; Rajendran, S.; Casey, G.; Scallan, M.; Harrison, P.; OSullivan, G.; Tangney, M. Comparison of DNA Delivery and Expression Using Frequently Used Delivery Methods. In Gene Therapy—Developments and Future Perspectives; InTechOpen: London, UK, 2011.

161. Marjanovič, I.; Kandušer, M.; Miklavčič, D.; Keber, M.M.; Pavlin, M. Comparison of Flow Cytometry, Fluorescence Microscopy and Spectrofluorometry for Analysis of Gene Electrotransfer Efficiency. J. Membr. Biol. 2014, 247, 1259-1267. [CrossRef] [PubMed]

162. Rathenberg, J.; Nevian, T.; Witzemann, V. High-efficiency transfection of individual neurons using modified electrophysiology techniques. J. Neurosci. Methods 2003, 126, 91-98. [CrossRef]

163. Peng, L.; Xiong, W.; Cai, Y.; Chen, Y.; He, Y.; Yang, J.; Jin, J.; Li, H. A simple, rapid method for evaluation of transfection efficiency based on fluorescent dye. Bioengineered 2017, 8, 225-231. [CrossRef]

164. Goedhart, J.; van Weeren, L.; Adjobo-Hermans, M.J.W.; Elzenaar, I.; Hink, M.A.; Gadella, T.W.J. Quantitative Co-expression of proteins at the single cell level - application to a multimeric FRET sensor. PLoS One 2011, 6, e27321. [CrossRef] [PubMed]

165. Armknecht, S.; Boutros, M.; Kiger, A.; Nybakken, K.; Mathey-Prevot, B.; Perrimon, N. High-throughput RNA interference screens in Drosophila tissue culture cells. In Methods Enzymology; Elsevier Inc.: Amsterdam, The Netherlands, 2005; Volume 392, pp. 55-73. 
166. Yun, C.; Dasgupta, R. Luciferase reporter assay in Drosophila and mammalian tissue culture cells. Curr. Protoc. Chem. Biol. 2014, 6, 7-23. [CrossRef] [PubMed]

167. Carter, M.; Shieh, J. Biochemical Assays and Intracellular Signaling. In Guide to Research Techniques in Neuroscience; Elsevier: Amsterdam, The Netherlands, 2015; pp. 311-343.

168. Mosaad, E.O.; Futrega, K.; Seim, I.; Gloss, B.; Chambers, K.F.; Clements, J.A.; Doran, M.R. Constraints to counting bioluminescence producing cells by a commonly used transgene promoter and its implications for experimental design. Sci. Rep. 2019, 9, 1-2. [CrossRef] [PubMed]

169. Zhao, Q.Q.; Chen, J.L.; Lv, T.F.; He, C.X.; Tang, G.P.; Liang, W.Q.; Tabata, Y.; Gao, J.Q. N/P ratio significantly influences the transfection efficiency and cytotoxicity of a polyethylenimine/chitosan/DNA complex. Biol. Pharm. Bull. 2009, 32, 706-710. [CrossRef] [PubMed]

170. Zhang, P.; Wagner, E. History of Polymeric Gene Delivery Systems. Top. Curr. Chem. 2017, 375, 1-39.

171. il Kim, T.; Bai, C.Z.; Nam, K.; Park, J. Comparison between arginine conjugated PAMAM dendrimers with structural diversity for gene delivery systems. J. Control. Release 2009, 136, 132-139. [CrossRef]

172. Kroll, A.; Pillukat, M.H.; Hahn, D.; Schnekenburger, J. Current in vitro methods in nanoparticle risk assessment: Limitations and challenges. Eur. J. Pharm. Biopharm. 2009, 72, 370-377. [CrossRef]

173. Schulze, C.; Kroll, A.; Lehr, C.M.; Schäfer, U.F.; Becker, K.; Schnekenburger, J.; Schulze Isfort, C.; Landsiedel, R.; Wohlleben, W. Not ready to use-Overcoming pitfalls when dispersing nanoparticles in physiological media. Nanotoxicology 2008, 2, 51-61. [CrossRef]

174. Hamid, R.; Rotshteyn, Y.; Rabadi, L.; Parikh, R.; Bullock, P. Comparison of alamar blue and MTT assays for high through-put screening. Toxicol. Vitr. 2004, 18, 703-710. [CrossRef] [PubMed]

175. Salem, A.K.; Searson, P.C.; Leong, K.W. Multifunctional nanorods for gene delivery. Nat. Mater. 2003, 2, 668-671. [CrossRef]

176. Xiao, Y.P.; Zhang, J.; Liu, Y.H.; Zhang, J.H.; Yu, Q.Y.; Huang, Z.; Yu, X.Q. Low molecular weight PEI-based fluorinated polymers for efficient gene delivery. Eur. J. Med. Chem. 2019, 602-611. [CrossRef] [PubMed]

177. Liu, H.; Wang, Y.; Wang, M.; Xiao, J.; Cheng, Y. Fluorinated poly(propylenimine) dendrimers as gene vectors. Biomaterials 2014, 35, 5407-5413. [CrossRef] [PubMed]

178. Wang, H.Y.; Chen, J.X.; Sun, Y.X.; Deng, J.Z.; Li, C.; Zhang, X.Z.; Zhuo, R.X. Construction of cell penetrating peptide vectors with $\mathrm{N}$-terminal stearylated nuclear localization signal for targeted delivery of DNA into the cell nuclei. J. Control. Release 2011, 155, 26-33. [CrossRef] [PubMed] 